\title{
Observations and Prediction of Recovered Quality of Desalinated Seawater in the Strategic ASR Project in Liwa, Abu Dhabi
}

\author{
Pieter J. Stuyfzand ${ }^{1,2, *}$, Ebel Smidt ${ }^{3,4}$, Koen G. Zuurbier ${ }^{1}$, Niels Hartog ${ }^{1,5}$ \\ and Mohamed A. Dawoud ${ }^{6}$ \\ 1 KWR Watercycle Research Institute, 3430 BB Nieuwegein, The Netherlands; \\ koen.zuurbier@kwrwater.nl (K.G.Z.); niels.hartog@kwrwater.nl (N.H.) \\ 2 Faculty of Civil Engineering and Geosciences, Delft University of Technology, 2628 CN Delft, \\ The Netherlands \\ 3 Waterfocus, 3981 EB Bunnik, The Netherlands; ebel.smidt@waterfocus.nu or esmidt@sgmediation.nl \\ 4 SG Consultancy and Mediation Ltd, 5221 GB Engelen, The Netherlands \\ 5 Faculty of Geosciences, Utrecht University, 3508 TA Utrecht, The Netherlands \\ 6 Environment Agency Abu Dhabi, PO Box 45553, Al Mamoura Building (A), Muroor Road, Abu Dhabi, \\ United Arab Emirates; mdawoud@ead.ae \\ * Correspondence: pieter.stuyfzand@kwrwater.nl; Tel.: +31-6-10945021
}

Academic Editor: Maria Filomena Camões

Received: 14 January 2017; Accepted: 21 February 2017; Published: 1 March 2017

\begin{abstract}
To be able to overcome water shortages, Abu Dhabi Emirate started an Aquifer Storage and Recovery (ASR) project with desalinated seawater (DSW) as source water near Liwa. It is the largest DSW-ASR project in the world (stored volume $\sim 10 \mathrm{Mm}^{3}$ /year), and should recover potable water for direct use. DSW is infiltrated into a desert dune sand aquifer using "sand-covered gravel-bed" recharge basins. In this study, we evaluate the hydrogeological and hydrogeochemical stratification of the (sub)oxic target aquifer, and water quality changes of DSW during trial infiltration runs. We predict water quality changes of DSW after $824 \mathrm{~d}$ of infiltration, during $90 \mathrm{~d}$ of intensive recovery (67\% recovered) without storage (scenario A), as well as after 10 years of storage (scenario B, with significant bubble drift). Monitoring of preceding trials revealed a lack of redox reactions; little carbonate dissolution and $\mathrm{Ca} / \mathrm{Na}$ exchange; $\mathrm{much}^{\mathrm{SiO}}{ }_{2}$ dissolution; a strong mobilization of natural $\mathrm{AsO}_{4}{ }^{3-}$, B, $\mathrm{Ba}, \mathrm{F}, \mathrm{CrO}_{4}{ }^{2-}$, $\mathrm{Mo}, \mathrm{Sr}$ and $\mathrm{V}$ from the (sub)oxic aquifer; and immobilization of $\mathrm{PO}_{4}, \mathrm{Al}, \mathrm{Cu}$, $\mathrm{Fe}$ and Ni from DSW. The Easy-Leacher model was applied in forward and reverse mode including lateral bubble drift, to predict water quality of the recovered water. We show that hydrogeochemical modeling of a complex ASR-system can be relatively easy and straightforward, if aquifer reactivity is low and redox reactions can be ignored. The pilot observations and modeling results demonstrate that in scenario A recovered water quality still complies with Abu Dhabi's drinking water standards (even up to $85 \%$ recovery). For scenario B, however, the recovery efficiency declines to $60 \%$ after which various drinking water standards are exceeded, especially the one for chromium.
\end{abstract}

Keywords: Aquifer Storage and Recovery (ASR); hydrochemistry; desalinated seawater; chromate; trace elements; transport modeling; break-through curve; Abu Dhabi; recovery efficiency

\section{Introduction}

Water scarcity has driven many countries in arid zones, such as the Middle East and Abu Dhabi in particular, to desalinate large volumes of seawater for fresh water supply [1]. Episodic problems with seawater quality due to, e.g., harmful algae blooms [2,3] and oil spills, energy supply and fear of 
war or terrorism have nurtured the urgent need to store desalinated seawater in the underground for later use in case of a calamity [4-7].

In 2001, Abu Dhabi started its pioneer projects for developing strategic fresh water resources to face any emergency condition using the Aquifer Storage and Recovery (ASR) technique by infiltrating the surplus of desalinated water into the groundwater aquifer system. One of these projects is the strategic fresh water reserve project at Liwa. The project passed with success through the phases of first a feasibility study and subsequently a pilot study in 2003-2004 [8]. In this pilot, desalinated water was infiltrated in a dune sand aquifer system using injection wells as well as an underground recharge basin. The basin performed better than the ASR wells, and was therefore selected for implementation in the construction phase.

Construction of the full ASR plant started in 2009, and was finalized in Winter 2016. Large scale infiltration started in May 2015. The project aim is to infiltrate $26,500 \mathrm{~m}^{3} / \mathrm{d}\left(=9.7 \mathrm{Mm}^{3} /\right.$ year $)$ of desalinated water with Total Dissolved Solids (TDS) $<250 \mathrm{ppm}$ for $824 \mathrm{~d}$, in order to be able to cover an emergency water demand for $90 \mathrm{~d}$ with a recovery rate of $170,280 \mathrm{~m}^{3} / \mathrm{d}\left(=15.5 \mathrm{Mm}^{3} / 90 \mathrm{~d}\right)$ and a TDS of $\sim 400 \mathrm{ppm}$.

After extensive studies on the ASR recovery efficiency (the part of injected water that can be recovered with a satisfying quality), impact on groundwater tables and salinity distribution, and quality of the water to be recovered [8-12], questions persisted about a potential water quality deterioration during recovery after a prolonged storage period, with emphasis on critical $\mathrm{Cr}(\mathrm{VI})$ behavior. This related to the planned omission of a post-treatment of the recovered water, which was to be distributed directly without any treatment, as drinking water to Abu Dhabi City, trusting that the UAE drinking water standards [13] would not be exceeded. It was feared, however, in a late stage, that post-treatment would be needed requiring a costly facility, for two reasons. Firstly, the native groundwater in the project area contains elevated concentrations of, among others, TDS, $\mathrm{Cl}$, $\mathrm{SO}_{4}, \mathrm{~F}, \mathrm{Na}$ and $\mathrm{Cr}$ (as $\mathrm{CrO}_{4}{ }^{2-}$ ), exceeding the standards, suggesting that their mobilization would deteriorate water quality during prolonged storage. Secondly, water stored in ASR targeted aquifers generally displays significant quality changes due to redox reactions, cation exchange, desorption and dissolution of mineral phases [14-22].

In order to assess the impact of aquifer storage on the recovered water quality, we first investigated the hydrogeological, geochemical and hydrochemical stratification of the targeted aquifer system, based on available data [8-12]. We conducted a sampling campaign in the period of 3-7 August 2014 to check potential bias in the existing hydrochemical data set, and to obtain data on chromium speciation $(\mathrm{Cr}(\mathrm{III})$ versus $\mathrm{Cr}(\mathrm{VI}))$. Finally, we predicted the future quality of the recovered DSW after 27 months of infiltration, during $90 \mathrm{~d}$ of intensive recovery without storage, as well as after 10 years of storage (with significant lateral bubble migration).

This paper is based on two extensive reports $[23,24]$. It shows the peculiar characteristics of an eolian-fluvial sand (stone) aquifer system in a desert environment, the unique water quality changes during an ASR pilot including a six-year storage phase, and a particular modeling approach. In this approach, observations on retardation and leaching are combined with a strong schematization of the complex ASR system, flow, and processes.

\section{Materials and Methods}

\subsection{Field Site and Liwa ASR System}

The project area (Figures 1-3) is situated in a remote dune sand area $150 \mathrm{~km}$ southwest of Abu Dhabi City, some $25 \mathrm{~km}$ north of the Liwa Crescent (Al Qafa area). Its hydrological position is on or close to the phreatic groundwater divide of one of the few fresh groundwater reserves (Figure 2). The altitude of land surface varies between 120 and $160 \mathrm{~m}$ ASL (Above Sea Level).

The pilot area is $\sim 15 \mathrm{~km}$ to the east of the final Liwa ASR plant (Figure 3). The plant is composed of three underground basins A-C (Figure 3), each with 105 surrounding recovery wells, and 57 monitoring 
wells in total. The circular recharge basins A, B and C, $50 \mathrm{~m}$ in diameter, are composed of a flat gravel-body covered by geo-textile and a sand layer on top, fed by horizontal reverse drains.

The ASR plant is thus not a normal ASR system, which is exclusively composed of wells performing two tasks: infiltrate and recover [20].

\subsection{The Pilot}

The first operation run of the pilot started on 1 October 2003 and lasted until December 2004. DSW was infiltrated via a series of 5 ASR wells (not discussed further) and a recharge basin recovery scheme consisting of a covered gravel-body with reverse drains in it, 4 recovery wells and tens of observation wells around. DSW was infiltrated via the basin for $250 \mathrm{~d}$ at $\sim 250 \mathrm{~m}^{3} / \mathrm{h}$, and after $48 \mathrm{~d}$ of storage part of the stored volume was recovered in $70 \mathrm{~d}$ at $\sim 250 \mathrm{~m}^{3} / \mathrm{h}$. Intensive monitoring of water quality yielded important insights in the ambient hydrochemical stratification and water quality changes during infiltration, stand-still and recovery [8].

A second infiltration run via the basin took place in 2008 , but water quality monitoring was not undertaken and DSW was not pumped out. This offered the possibility to sample, in August 2014, 6-year-old DSW from the aquifer.

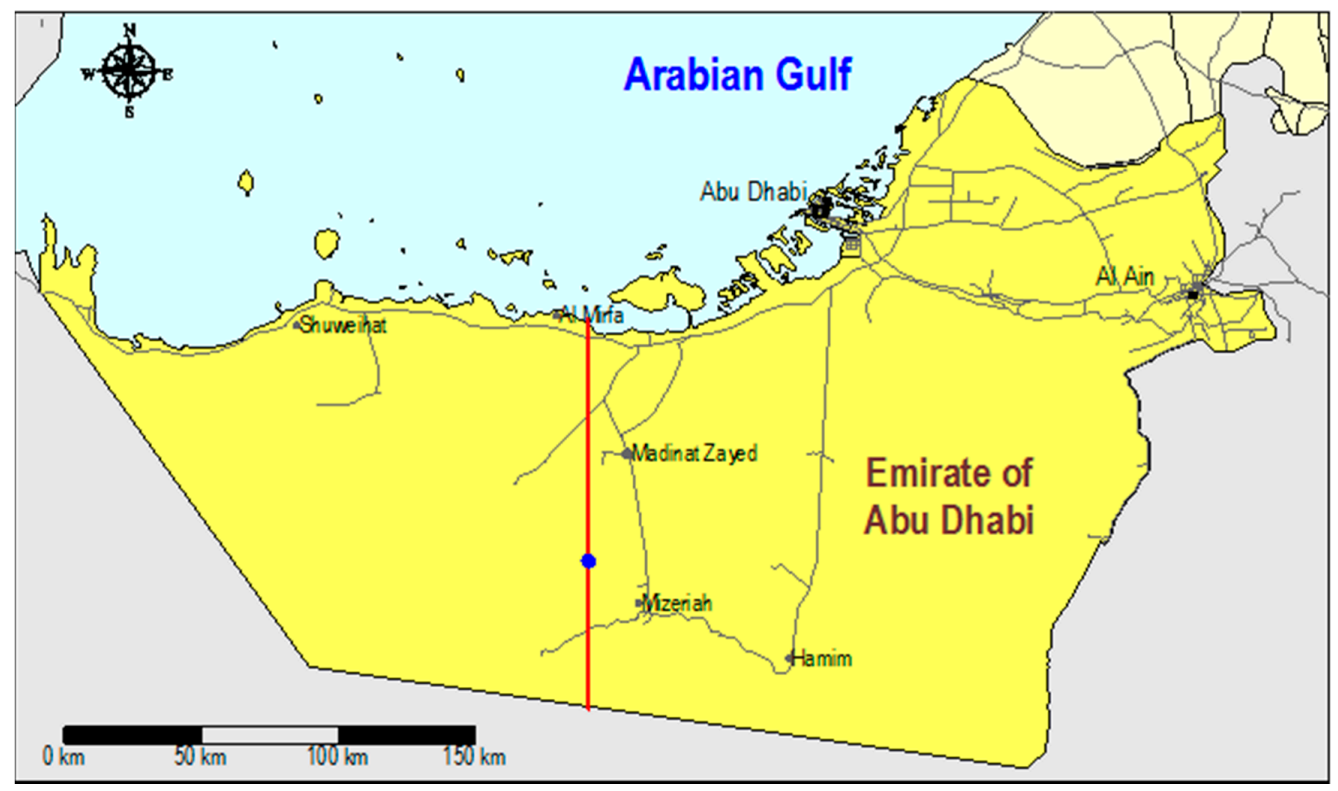

Figure 1. Location of the Liwa Strategic Water Storage and Recovery (SWSR) Project: the blue dot on the red line. From GTZ-Dornier (with permission): [10].

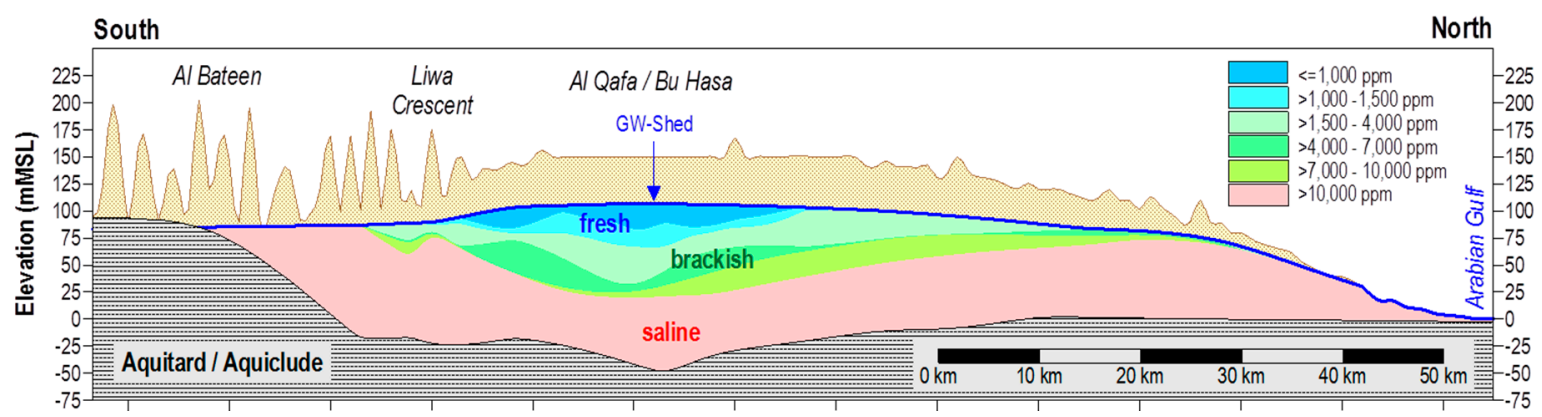

Figure 2. Cross section along red line in Figure 1, showing groundwater salinity distribution and position of groundwater divide where SWSR project. From GTZ-Dornier (with permission): [10]. 


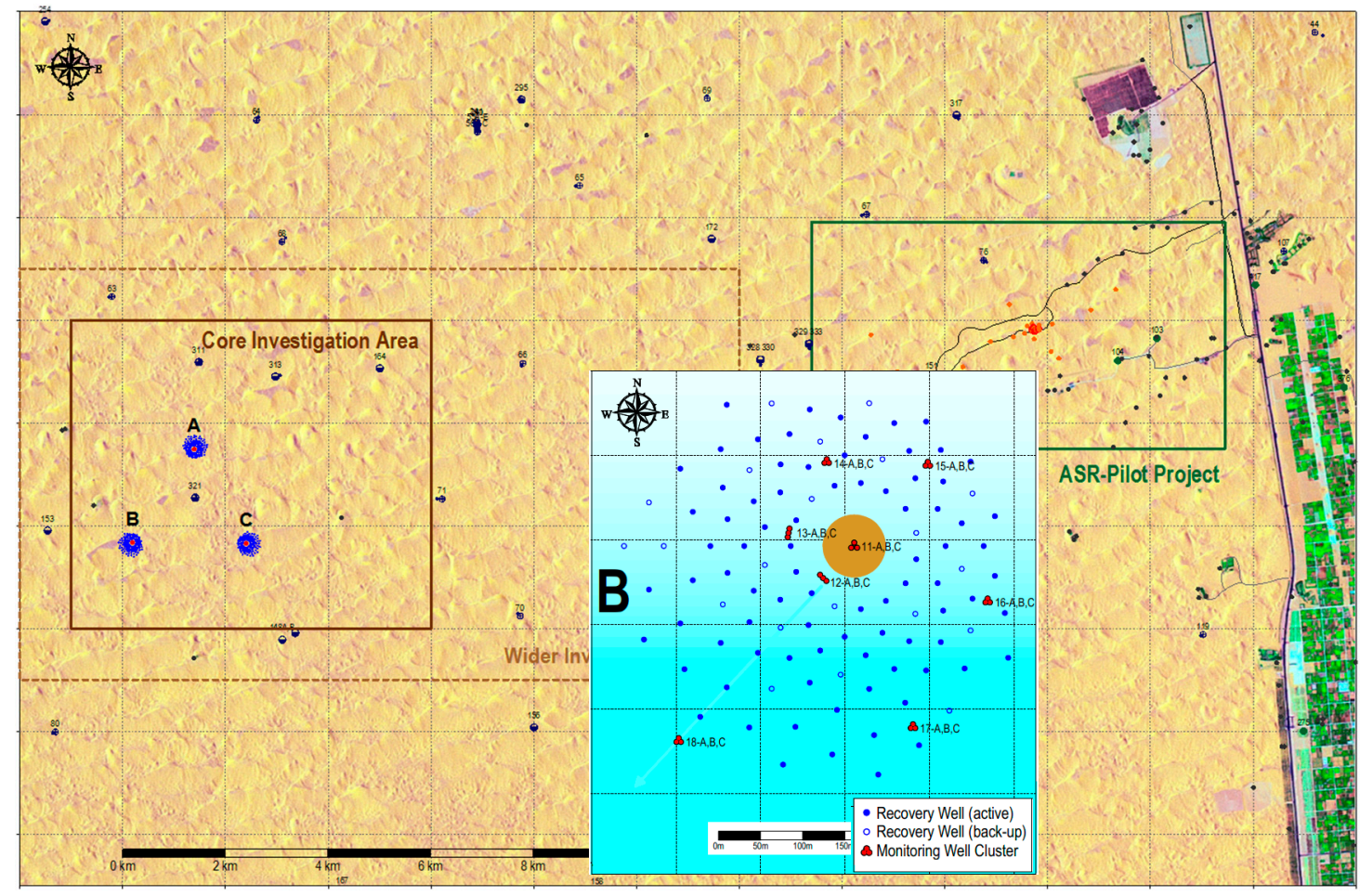

Figure 3. Detailed location map, showing the ASR pilot area and Liwa's SWSR well field clusters A, B and C, each surrounding a large circular underground recharge basin. Slightly modified from: GTZ-Dornier (with permission) [9].

\subsection{Quantitative Description of the Break-through Curve}

The first infiltration run of the pilot yielded valuable insight into the break-through curve (BTC) of nearly all main constituents and trace elements. These observed BTCs are characterized by 3 parameters: pore volume, retardation or leach factor and (semi)permanent concentration change (Figure 4).

The dimensionless parameter called "pore volume" (PV) forms the time axis of water quality observations and model predictions:

$$
P V=\frac{t_{I N F}}{t_{50}}
$$

where $t_{I N F}=$ total infiltration period $[\mathrm{d}]$; and $t_{50}=$ the observed $50 \%$ breakthrough time of conservative tracer or the calculated travel time via Equation (4).

One PV means that the whole aquifer, from infiltration point to the monitoring or recovery well, has been flushed with the infiltration water exactly one time. Retardation factors $\mathrm{R}$ or leach factors $\mathrm{L}$ can then be simply deduced from concentration plots against PVs (Figure 4).

Sorbing and oxidizing solutes as well as desorbing and dissolving solutes are retarded during aquifer passage compared with conservative solutes. In the latter case, raised concentrations drop to the influent level long after passage of the conservative chloride front. These delays are quantified for solute $i$ by, respectively, the well-known retardation factor $R_{i}$, and the less well known leach factor $L_{i}$ [25]:

$$
\begin{gathered}
R_{i}=\frac{t_{i}}{t_{50}}=1+\frac{\rho_{S}(1-n) K_{d}}{n} \\
L_{i}=\frac{t_{i}}{t_{50}}=1+\frac{\rho_{S}(1-n)(\text { solid })}{n(\text { reac }) r_{R}}=1+\frac{\rho_{S}(1-n)(\text { solid })}{n(\text { prod }) r_{P}}
\end{gathered}
$$


where $t_{i}=$ time required for $\geq 90 \%$ break-through $\left(R_{i}\right)$ or $\geq 90 \%$ leaching $\left(L_{i}\right)$ or till equilibrium is attained with the infiltration water [days]; $\rho_{s}=$ density of solids of porous medium $[\mathrm{kg} / \mathrm{L}] ; n=$ porosity $[\mathrm{L} / \mathrm{L}] ; K_{d}=$ distribution coefficient (slope of the linear portion of the adsorption isotherm) $[\mathrm{L} / \mathrm{kg}]$; $($ solid $)=$ content of reactive phase in aquifer $[\mathrm{mmol} / \mathrm{kg}$ dry weight $] ;($ reac $)=$ concentration of reactant in flushing fluid $[\mathrm{mmol} / \mathrm{L}] ;($ prod $)=$ concentration of reaction product in fluid during leaching $[\mathrm{mmol} / \mathrm{L}]$; $r_{R}=$ reaction coefficient, i.e., the number of mmoles of solid phase which is leached by 1 mmole of reactant [-]; and $r_{P}=$ reaction coefficient related to (prod).

For practical reasons, $t_{i}$ is set at $\geq 90 \%$ not at $100 \%$. If for some reason, the BTC shows a partial breakthrough due to a prolonged phase of continued partial immobilization or mobilization, so the additional parameter $\Delta C$ is needed to describe the BTC (Figure 4). Equations (2) and (3) hold for a stationary retardation or leaching process, with a homogeneously distributed reactive phase in the aquifer. Of course, (reac) or (prod) should have no other sinks or sources, unless these can be properly accounted for.

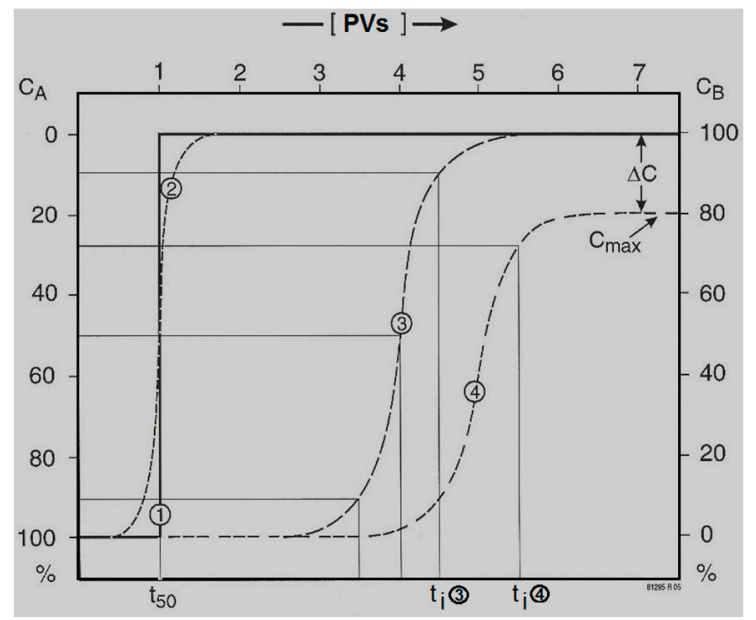

(A)

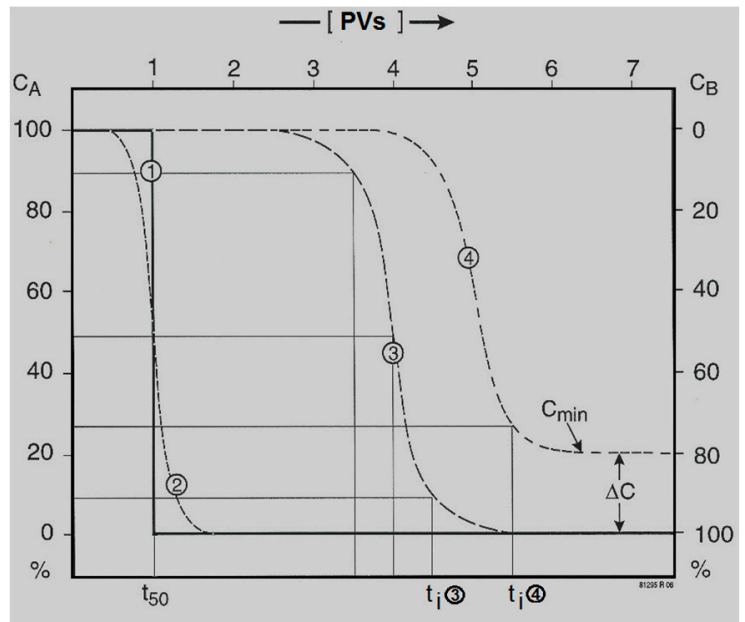

(B)

Figure 4. Characterization of the breakthrough of a compound dissolved in fluid B (concentration $C_{B}$ ), which displaces fluid A (concentration $C_{A}$ ), in terms of travel time $\left(t_{50}\right)$ and $90 \%$ break-through or leach times $\left(t_{i} ; t_{i} 3, t_{i} 4=t i\right.$ for curve 3 and 4 , respectively), the dimensionless parameter PV (pore volumes flushed) and the (semi)permanent concentration change $(\Delta C)$, the maximum concentration $\left(C_{\max }\right)$ or minimum concentration $\left(\mathrm{C}_{\min }\right)$ after full break-through or leaching. Line $1=$ conservative tracer $(\mathrm{R}=\mathrm{L}=1$ ) without dispersion; Curve 2 = as 1 , however, with dispersion; Curve 3 = compound retarded by sorption or leaching $(\mathrm{R}=\mathrm{L}=4)$; Curve $4=$ compound retarded by ad- or desorption $(\mathrm{R}=\mathrm{L}=5)$, with continued removal c.q. addition. (A) $\left(C_{B}>C_{A}\right)$; and $(B)\left(C_{B}<C_{A}\right)$.

\subsection{Lithological and Geochemical Stratification}

The aquifer system on well fields A, B and C could be schematized into a succession of 14 (sub) horizontal layers in between ground surface and $40 \mathrm{~m}$ below sea level [23], based on all drilling logs (>372), geophysical logs (including the eccentered wireline NMR logging of permeability and porosity), pumping tests, infiltration pilot tests and fluid flow logging, as presented by [9-12]. For modeling purposes, the 14 layers were aggregated into 6 main aquifer layers (a-f in Figure 5), of which the very low permeability aquitard $\mathrm{f}$ needs less consideration. 


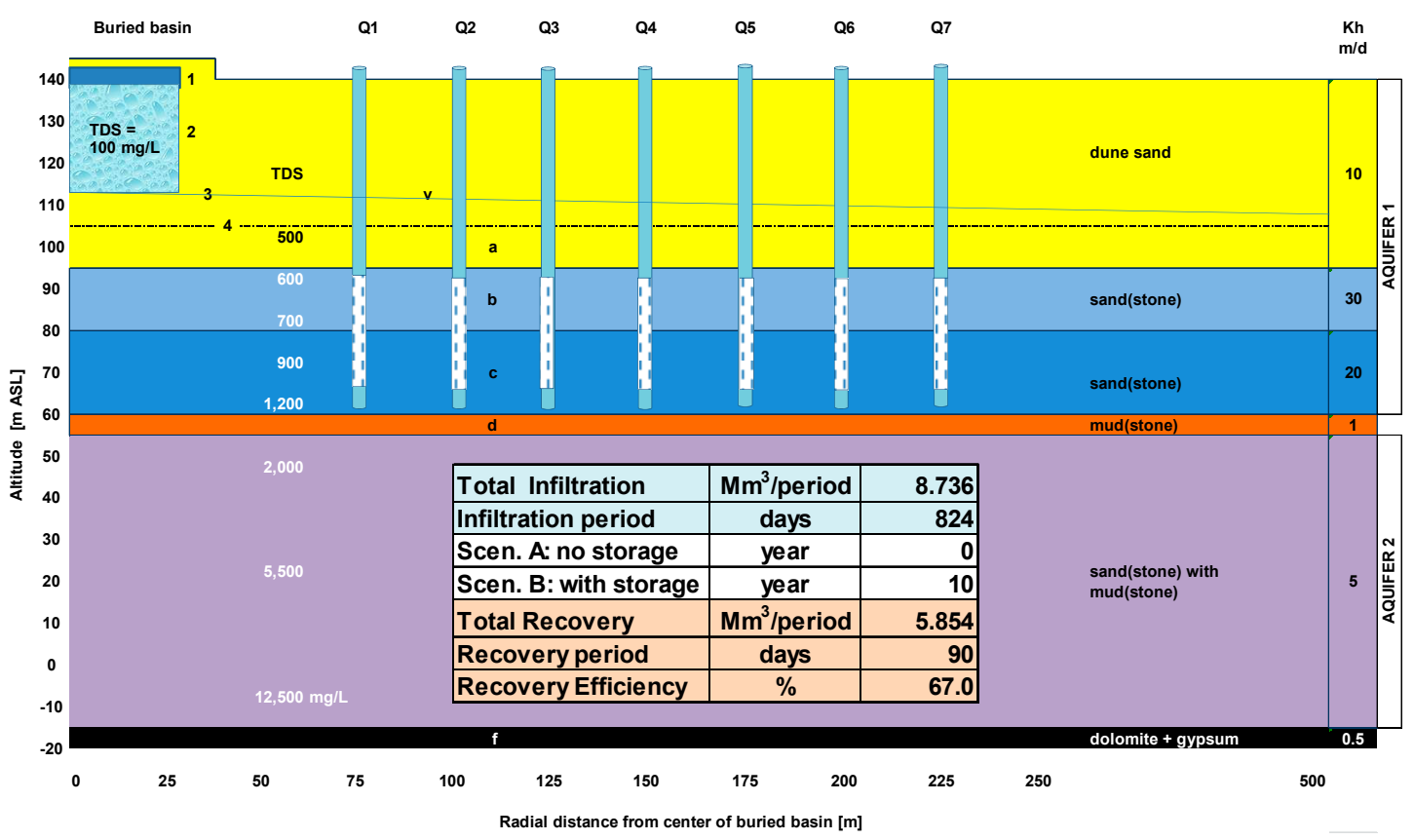

Figure 5. Schematic of each ASR well field (A, B or C) in the Strategic Water Storage and Recovery project in Liwa, with the planned ASR cycling scheme for each well field. Q1-Q7 = annular circle numbers 1-7 with 15 recovery wells each, surrounding the central infiltration basin. 1 = buried basin; $2=$ unsaturated flow of infiltrated DSW; 3 = groundwater table during infiltration; 4 = groundwater table prior to recharge. $\mathrm{a}-\mathrm{f}=$ aggregation of layers $1-14 . \mathrm{d}=$ aquitard $1, \mathrm{f}=$ aquitard 2 . Each well is supposed to pump from aquifer layers $\mathrm{a}, \mathrm{b}$ and $\mathrm{c}$ in proportion to their transmissivity.

The mean geochemical composition of layers a- $\mathrm{f}$ was calculated from the geochemical data of 4 deep core drillings, one in each well field and one in the middle of well fields A, B and C. The data were derived from [12], containing the following information: Sample description with photographs, petrographic analysis and mineralogical counting by petrological photomicroscopic examination of a thin section impregnated with fluorescent resin, XRD analysis, porosimetric analysis, chemical analysis of main constituents (including LOI and Acid Solubility), chemical analysis of heavy metals (probably in nitric acid; no details given), and particle size distribution (by sieving).

The digital data of all 41 samples were used to calculate mean values for aquifer layers a-f, and to quantify the content of selected minerals by petrochemical calculations [23]. Petrochemical calculations were needed to correct specific data for water losses (loss on ignition), to calculate the cation exchange capacity (CEC) and to derive the mineral content from data on elements that are present in more than one mineral.

\subsection{Hydrochemical Analyses in Period 2003-2013}

Samples were taken from practically all recovery and monitoring wells, in both the pilot area and well fields $\mathrm{A}, \mathrm{B}$ and $\mathrm{C}$. The analyses include data on gases $\left(\mathrm{O}_{2}\right.$, residual $\left.\mathrm{Cl}_{2}\right)$, turbidity, color, temperature, $\mathrm{pH}, \mathrm{EC}$, ORP (Oxidation Reduction Potential, Eh), main anions $\left(\mathrm{Cl}, \mathrm{SO}_{4}, \mathrm{~S}, \mathrm{HCO}_{3}, \mathrm{CO}_{3}\right.$, $\mathrm{NO}_{3}, \mathrm{NO}_{2}, \mathrm{PO}_{4}$, and $\mathrm{F}$ ), main cations ( $\mathrm{Na}, \mathrm{K}, \mathrm{Ca}, \mathrm{Mg}, \mathrm{NH}_{4}, \mathrm{Fe}$, and $\mathrm{Mn}$ ), $\mathrm{SiO}_{2}, \mathrm{TOC}$ (Total Organic Carbon), CN, selected trace elements ( $\mathrm{Ag}, \mathrm{Al}, \mathrm{As}, \mathrm{B}, \mathrm{Ba}, \mathrm{Br}, \mathrm{Cd}, \mathrm{Cr}, \mathrm{Cu}, \mathrm{Hg}, \mathrm{Mo}, \mathrm{Ni}, \mathrm{Pb}, \mathrm{Sb}, \mathrm{Se}, \mathrm{Sr}, \mathrm{V}$ and $\mathrm{Zn}$ ), and the stable isotopes ${ }^{2} \mathrm{H}$ and ${ }^{18} \mathrm{O}$. Most samples were filtered in the field, and all concentrations (TOC excluded) refer to total dissolved concentrations, thus without (further) speciation. Microbial parameters and organic micropollutants were analyzed but showed negligible concentration levels.

Samples of the ambient groundwater were taken in the pilot area in 2003, and within and around well fields A, B and C in 2011-2013. Analytical data of DSW samples prior to infiltration, during and 
after aquifer passage were exclusively available from the pilot. All data (obtained from [9-12] and from data files supplied by Dr. G. Koziorowski (GTZ International Services) were controlled, elaborated and stored with Hydrogeochemcal.xlsx [26].

\subsection{Monitoring Campaign in August 2014}

In the period of 3-7 August 2014 a sampling campaign was conducted to take 31 samples from divergent observation wells that had been sampled earlier and from DSW, in order to: (i) check potential bias in the existing hydrochemical data set of well fields A, B and C; and (ii) obtain data on chromium speciation: $\mathrm{Cr}(\mathrm{III})$ versus $\mathrm{Cr}(\mathrm{VI})$.

Important aspects that were tackled with great care, are: sufficient well purging based on purged volume and stable field parameters, sampling without applying vacuum and excluding atmospheric exposition, reducing exposure to sunlight and wind, flow regulation of the pump, field measurements (EC, $\mathrm{pH}$, temp, $\mathrm{O}_{2}$ ), filtration of water over a $0.45 \mu \mathrm{m}$ membrane, dedicated sample preservation for specific parameter groups, cooling, nearly daily shipment to the Netherlands, and rapid analysis in the certified Vitens Laboratory (Leeuwarden). The quality of the analysis was validated using HGC 2.0 to exclude potential impact of errors.

\subsection{Predictions by EL Modeling}

Two models were constructed, an Excel based Easy-Leacher (EL) model [25] and a PHREEQC-2 [27] flowtube model.

PHREEQC-2 was applied to model more in detail the behavior of chromate and arsenate along a small number of flowlines during infiltration phase. PHREEQC-2 and EL produced nearly identical results for chromate and arsenate behavior during infiltration, justifying the application of the simpler EL model. Further details about the PHREEQC-2 modeling and its results are given by [24] and not considered here further.

EL simplifies 3D groundwater flow into a 2D set of maximum 50 flow tubes through a maximum of 10 horizontal aquifer layers. The travel times are either derived from a hydrological model, or calculated analytically. Chemical transport is calculated on the basis of pore volumes (dimensionless time scale), retardation and leach factors (superimposed on the pore volumes) based on either mass balances or field observations, $\mathrm{CaCO}_{3}$ equilibrium (if relevant), redox reactions (if relevant), and expert rules on among others redox reaction kinetics.

EL was given the task to do the all-round water quality modeling during all ASR phases (infiltration, storage with bubble drift, and recovery), and to combine the output of a relatively high number of flowlines into a mixed output as generated by a well field.

In EL, the whole ASR system was schematized by one representative recharge basin (the average of basins $\mathrm{A}-\mathrm{C}$ ), 5 aquifer layers (of which the upper layers $\mathrm{a}, \mathrm{b}$ and $\mathrm{c}$ are most important) and 7 flowlines within each aquifer layer departing from the basin towards one recovery well in each of the 7 well rings at $75-225 \mathrm{~m}$ radius (Figure 5).

The expansion of the DSW bubble in each aquifer layer and the travel times along each flowline were calculated by assuming first vertical flow down to each aquifer layer and then horizontal radial flow, so that:

$$
t_{N}=\frac{n_{N} \pi r^{2} T}{Q_{I N} K_{h, N}}+t_{V}
$$

where: $t_{N}=50 \%$ break-through time $\left(t_{50}\right)$ in layer $\mathrm{N}[\mathrm{d}] ; n_{N}=$ porosity of layer $\mathrm{N}[-] ; r=$ radial distance from the basin center $[\mathrm{m}] ; T=$ transmissivity of the aquifer $\left[\mathrm{m}^{2} / \mathrm{d}\right] ; Q_{I N}=$ mean infiltration rate $\left[\mathrm{m}^{3} / \mathrm{d}\right] ; K_{h, N}=$ horizontal hydraulic conductivity of layer $\mathrm{N}[\mathrm{m} / \mathrm{d}]$; and $t_{V}=$ vertical travel time $[\mathrm{d}]$ as determined by a 3D hydrological model [8].

This simplification creates some distortion during the first $30 \mathrm{~d}$, but these are of minor importance on the long run of $824 \mathrm{~d}$ of infiltration. With Equation (4), the travel time was calculated from recharge basin to its 7 surrounding rings of recovery wells at the distances specified in Figure 6. It is deduced 
that in theory all wells, also those in the outermost ring will pump DSW after $824 \mathrm{~d}$ of infiltration. In layers D and E, probably little DSW will be present.

\begin{tabular}{|c|c|c|c|c|c|c|c|c|c|c|}
\hline \multirow{6}{*}{$\begin{array}{l}\stackrel{0}{\underline{\Xi}} \\
\overline{\overline{0}} \\
3\end{array}$} & & & \multicolumn{8}{|c|}{ Well circle number } \\
\hline & \multirow{5}{*}{$\begin{array}{c}\text { Wells in } \\
\text { indicated } \\
\text { circle } \\
\text { number }\end{array}$} & No. & 1 & 2 & 3 & 4 & 5 & 6 & 7 & mean \# \\
\hline & & $r$ [m] & 75 & 100 & 125 & 150 & 175 & 200 & 225 & 140 \\
\hline & & n $\$$ & 12 & 13 & 12 & 12 & 12 & 12 & 11 & 12 \\
\hline & & m3/h/well & 45 & 35 & 35 & 35 & 25 & 25 & 25 & 32.1 \\
\hline & & flux $\%$ & 20.0 & 15.6 & 15.6 & 15.6 & 11.1 & 11.1 & 11.1 & 14.3 \\
\hline \multirow{5}{*}{ 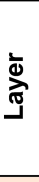 } & $\mathbf{a}$ & \multirow{5}{*}{$t_{N} \quad(d)$} & 65 & 111 & 170 & 243 & 329 & 429 & 541 & 239 \\
\hline & b & & 29 & 42 & 59 & 80 & 104 & 132 & 164 & 78 \\
\hline & c & & 52 & 77 & 109 & 148 & 195 & 248 & 309 & 146 \\
\hline & d & & 1017 & 1704 & 2586 & 3665 & 4940 & 6410 & 8077 & 3600 \\
\hline & $\mathbf{e}$ & & 2083 & 3508 & 5341 & 7581 & 10229 & 13284 & 16746 & 7446 \\
\hline \multirow{5}{*}{ ঐ্త } & $a$ & \multirow{5}{*}{ PV } & 12.8 & 7.4 & 4.8 & 3.4 & 2.5 & 1.9 & 1.5 & 5.6 \\
\hline & b & & 28.5 & 19.6 & 14.0 & 10.4 & 7.9 & 6.2 & 5.0 & 14.7 \\
\hline & c & & 15.8 & 10.7 & 7.5 & 5.6 & 4.2 & 3.3 & 2.7 & 8.0 \\
\hline & d & & 0.8 & 0.5 & 0.3 & 0.2 & 0.2 & 0.1 & 0.1 & 0.4 \\
\hline & e & & 0.4 & 0.2 & 0.2 & 0.1 & 0.1 & 0.1 & 0.0 & 0.2 \\
\hline
\end{tabular}

$\$=$ active wells of 15 in each ring; \# = flux weighted mean

Figure 6. Calculated travel times $\left(t_{N}\right)$ to the 7 well rings around each recharge basin during infiltration, in aquifer layers a-e, and the number of pore volumes (PV) after $824 \mathrm{~d}$ of nonstop infiltration. $\mathrm{PV}=824 / t_{N}$. Orange cells have $\mathrm{PV}<1$, indicating that DSW did not arrive during the recharge period.

During 10 years of storage, the infiltrated DSW bubble is predicted to move laterally down the regional hydraulic gradient, with the following velocity $\left(v_{B, N}\right)$, assuming an equal gradient in each layer:

$$
v_{B, N}=\frac{K_{h, N} \Delta H}{n_{N} \Delta X}
$$

where $\Delta H / \Delta X=$ mean regional hydraulic gradient in the aquifer at well fields $\mathrm{A}, \mathrm{B}$ and $\mathrm{C}$ during storage phase $[\mathrm{m} / \mathrm{m}]$.

Vertical bubble drift by buoyancy has been ignored in accordance with FEFLOW model predictions [9]. The water quality evolution during injection phase was calculated for each flowline where it crossed its destination well (node point), and also for the "fictive", mixed sample taken from all 35 node points, in proportion to: (i) the preset pumping regime (the inner wells pumping more than the outer wells); and (ii) the transmissivity of each main contributing aquifer layer $(a-c)$. This mixed sample thus represents the output from the whole well field, when pumping out a negligible amount of water without disturbing the continuous DSW bubble expansion.

EL in forward mode assumes the following: (1) input quality (DSW) is constant; (2) retardation factors, leach factors and the (semi)permanent concentration changes are derived from observations during the pilot; (3) redox reactions are absent as observed in the pilot; (4) reactive minerals such as calcite, dolomite and silicates are not depleted; and (5) reaction kinetics do not play an important role.

The recovery phase was modeled by moving backward in the time series that displays the quality evolution of this "imaginary", mixed (averaged) water sample. Contrary to the infiltration phase, this "imaginary", mixed sample now becomes the true output of the well field during recovery phase, showing after some time an increasing instead of decreasing contribution of native groundwater. This is in harmony with theory and the predictions by [9,11].

As during the $90 \mathrm{~d}$ of recovery $67 \%$ of the infiltrated water volume will be pumped out, the way back in the expansion time series needs to be as long as $0.67 \times 824=552 \mathrm{~d}\left(=\Delta \mathrm{t}_{\mathrm{BACK}-1}\right)$. This way, water quality at the start of recovery, without storage phase, will be the water that flushed each of the 7 well rings prior to pumping (on day 824), and this water only needs to be mixed in proportion to the pumping rates of each well ring (Figure 6). At the end of pumping (after $90 \mathrm{~d}$ ) we obtain about the same water as predicted to surround the wells on day $824-552=272$. Water compositions in 
between can be calculated by just following the predicted water quality from 824 to $272 \mathrm{~d}$ back in time. In order to plot this water quality evolution during $90 \mathrm{~d}$ of recovery, the expanded time scale (from 90 to $552 \mathrm{~d}$ ) needs to be compressed back again to $90 \mathrm{~d}$, by multiplying it with $90 / 552$, and to mirror it from backward into forward mode (Figure 7).

In the case of a 10-year storage phase, lateral bubble drift can be taken into account by first extending the backward period of $552 \mathrm{~d}\left(\Delta \mathrm{t}_{\mathrm{BACK}-1}\right)$ with the period $\left(=\Delta \mathrm{t}_{\mathrm{BACK}-2}\right)$ that would be needed to get the retrograded bubble face back on its position at $552 \mathrm{~d}$ without bubble drift, and then resetting

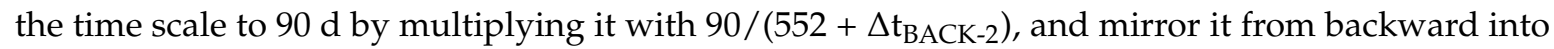
forward mode (Figures 7 and 8).

The calculation of $\Delta t_{\mathrm{BACK}-2}$ is then as indicated in the realistic example elaborated in Figure 8. In order to simplify the calculations, the weighted average value of $\Delta \mathrm{t}_{\mathrm{BACK}-2}$ is taken, being $174 \mathrm{~d}$ in the example of Figure 6. Addition of $\Delta \mathrm{t}_{\mathrm{BACK}-2}=552$ yields a total set-back time of $726 \mathrm{~d}$. This means that the quality of the water recovered after $90 \mathrm{~d}$ of pumping, is to be looked up in the quality output list on day $824-726=98$, in case of bubble drift during 10 years of storage.

How this example with resulting time shifts works out in the \%DSW and TDS concentration of the water recovered, is shown in Figure 7. The underlying calculations were performed in EL, and match the predictions by [9] quite well.

EL in backward mode assumes that: (a) the forward evolution is reversed at 6 times higher speed; (b) the 6 times higher recovery rate does not provoke serious upconings (as shown by 3D modeling results [9]; and (c) during storage and recovery no further reactions with the aquifer are taking place.

Fluxes in the different aquifer layers, from the recharge basin towards the recovery wells and beyond them, were set equal to their contribution to the aquifer's transmissivity.

Model calibration was done on: (1) available data from the pilot study in 2003-2004 when DSW was infiltrated via a recharge basin; and (2) groundwater quality as observed in the same pilot area in August 2014, after about 6 years of storage in the local aquifer system (since a second recharge run in 2008).

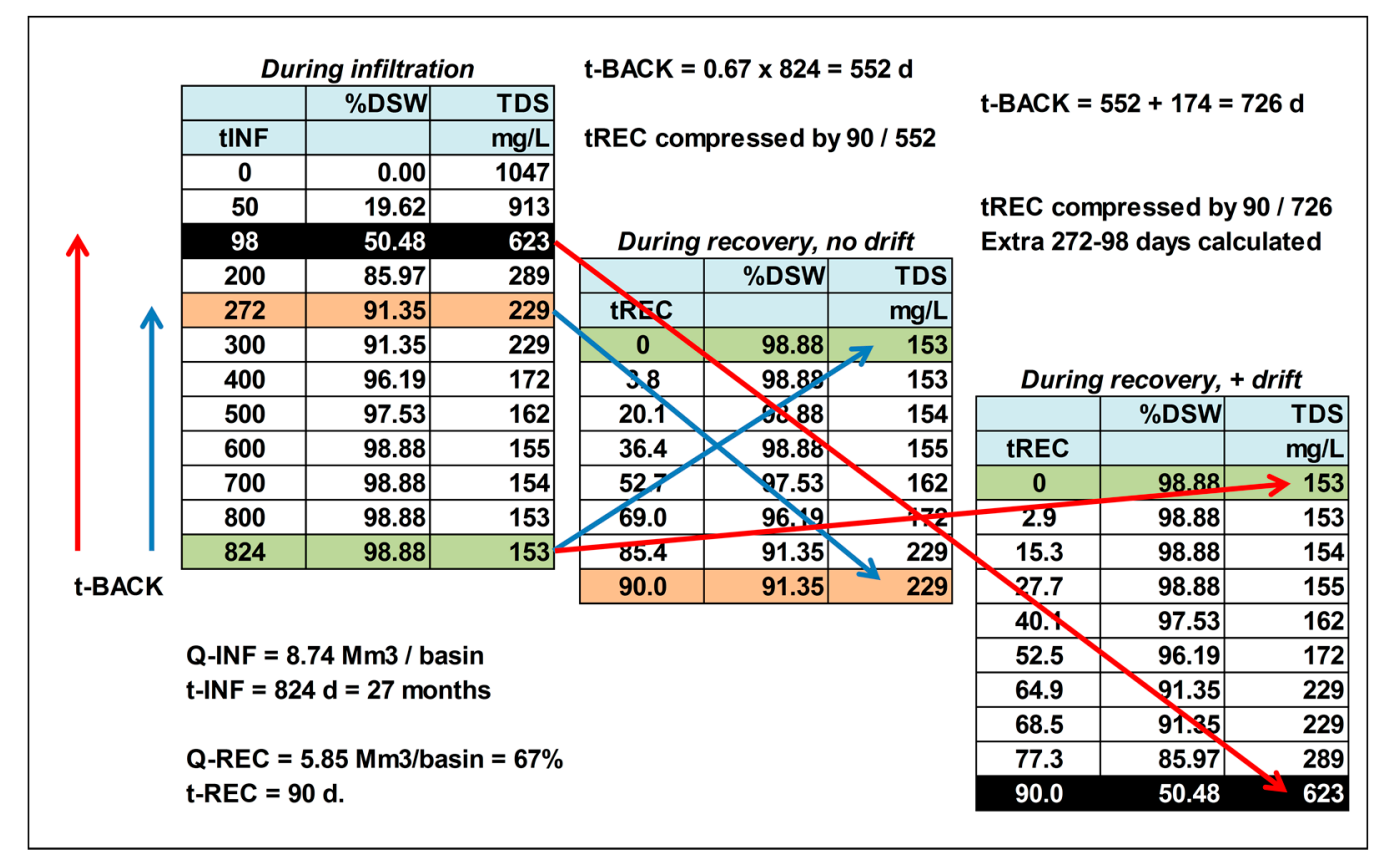

Figure 7. Explanation to how the predicted "fictive" mixed water quality at the recovery wells during $824 \mathrm{~d}$ of infiltration is used in backward mode, for predicting water quality during $90 \mathrm{~d}$ of recovery, without or with bubble drift effects. The forward EL prediction is reversed and its time axis compressed. 


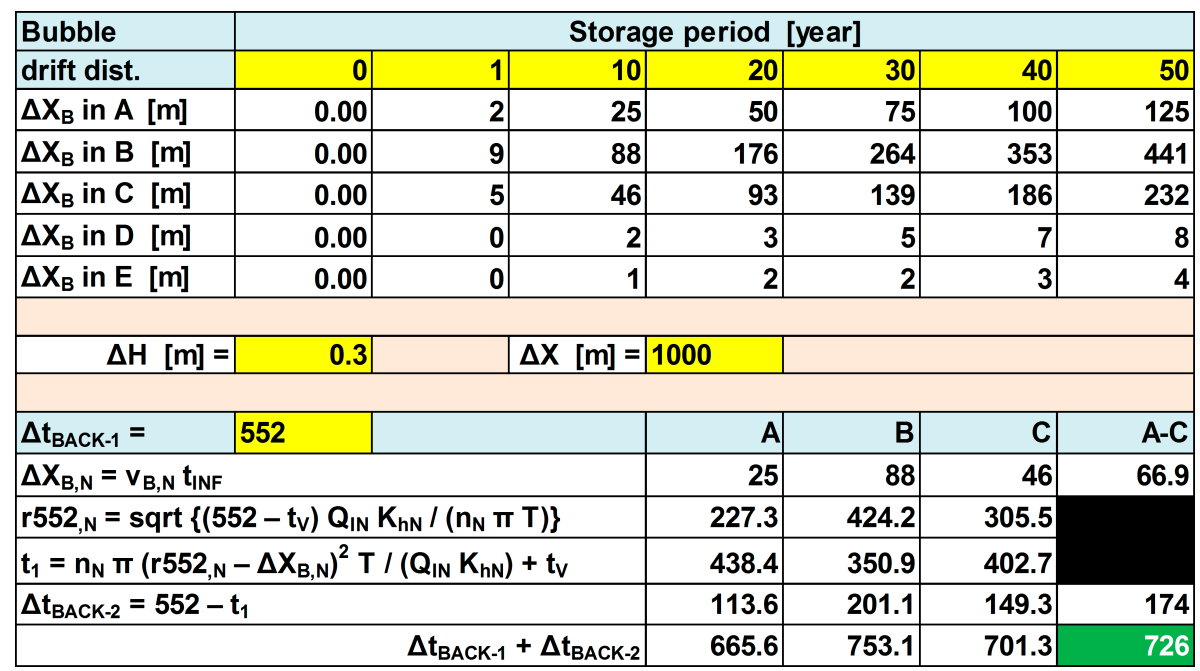

Figure 8. Calculated horizontal bubble drift $\left(\Delta X_{B}\right)$ as function of aquifer layer and storage time, for the Liwa aquifer system, and its impact on the set-back time $\Delta t_{B A C K-2}$. Together with the set-back time due to recovery $\left(\Delta t_{\text {BACK-1 }}\right)$, a total set-back time of $726 \mathrm{~d}$ is obtained. Further explanation can be found in the text and in the list of abbreviations (end of paper).

\section{Results of Hydrogeological, Geochemical and Hydrochemical Stratification Analysis}

\subsection{Hydrogeology}

The hydrogeological schematization is presented in Figure 5. It shows an upper aquifer with transmissivity $768 \mathrm{~m}^{2} / \mathrm{d}$, formed by layers a-c, which consist of reddish to yellowish brown, eolian sand(stone) of Quaternary age. It is unsaturated in its upper $30 \mathrm{~m}$, and consists there mostly of uncemented or weakly cemented sand. From the groundwater table downwards to the aquifer base at $62 \mathrm{~m}$ ASL, an alternation is observed of semi-consolidated and weakly to moderately cemented sands and sandstone.

Aquitard 1 and Aquifer 2, between $62 \mathrm{~m}$ ASL and $14 \mathrm{~m}$ BSL, likely correspond to the Pleistocene Medinat Zayed formation, consisting of mainly eolian and some fluvial and lacustrine deposits [11]. It is composed of yellowish brown to red brown to gray calcarenaceous sandstone with intercalations of siltstone, mudstone, marl and thin sand lenses.

Aquitard 2, at the base of the considered aquifer complex, is composed of a Neogene formation [11], consisting of light gray to white calcarenite, limestone and dolomite with interbeds of white to pinkish gypsum, marl, and chalk.

\subsection{Geochemistry}

The mean geochemical stratification (Table 1) follows more or less the hydrogeological subdivision (Figure 5). The interpreted data reveal the presence of the following reactive phases in the aquifer system, with their main potential interaction with water within brackets: Bulk Organic Material (denitrification, sorption), clay minerals (sorption), iron (hydr)oxide coatings of sand grains (source of Fe and oxyanions like chromate, vanadate and arsenate), calcite and dolomite (or dolomitic limestone; source of $\mathrm{Ca}, \mathrm{Mg}, \mathrm{Sr}$ and $\mathrm{HCO}_{3}$ ), feldspars (source of $\mathrm{Na}, \mathrm{Ca}$ and $\mathrm{SiO}_{2}$ ), gypsum (source of $\mathrm{Ca}, \mathrm{Sr}$ and $\mathrm{SO}_{4}$ ), pyroxene (source of oxyanions like chromate, vanadate and arsenate), and (fluoro)apatite (source of $\mathrm{Ca}, \mathrm{PO}_{4}$ and $\mathrm{F}$ ). Gypsum and dolomite were concentrated in aquitard 2 (at the base), feldspar and iron (hydr)oxides in aquifer 1 (the top).

The eolian sand is typically coated with iron (hydr)oxide, and more or less cemented mainly by calcite. The iron hydroxide coatings are considered to be the main (but genetically the secondary) source of oxyanions like chromate $[\mathrm{Cr}(\mathrm{VI})]$, vanadate, molybdate, selenate, arsenate and phosphate. 
These negatively charged ions are (chemi)sorbed to these positively charged coatings, and may desorb from it under specific conditions.

Another mineral frequently mentioned by [12], in concentrations of $\leq 1 \%$, is pyroxene. Pyroxenes are of particular interest due to their potential contribution to $\mathrm{Cr}$. Their composition is as follows: $\mathrm{XY}(\mathrm{Si}, \mathrm{Al})_{2} \mathrm{O}_{6}$ with $\mathrm{X}$ representing $\mathrm{Ca}, \mathrm{Na}, \mathrm{Fe}(\mathrm{II}), \mathrm{Mg}$ and more rarely $\mathrm{Zn}, \mathrm{Mn}$ and lithium, and $\mathrm{Y}$ representing $\mathrm{Cr}, \mathrm{Al}, \mathrm{Fe}(\mathrm{III}), \mathrm{Mg}, \mathrm{Mn}, \mathrm{Sc}$, Ti and $\mathrm{V}$. There is indeed a good positive correlation between $\mathrm{Cr}, \mathrm{Al}, \mathrm{Fe}, \mathrm{Ni}, \mathrm{Ti}, \mathrm{V}$ and $\mathrm{Zn}$ [23], indicating that pyroxenes could be a significant primary source of $\mathrm{Cr}$. No mention was made of the occurrence of olivine, another mineral typical of ophiolites, which [28] suspect as being the primary source of $\mathrm{Cr}$ in Abu Dhabi's groundwater. This mineral has a high weathering thus low resistance potential, and has possibly therefore not been found.

\subsection{Chemistry of Native Groundwater}

The strong vertical zonation of water qualities in the aquifer system is mainly linked to a rising salinity (TDS) with depth (Figure 5). The latter is dictated by the presence of shallow "fresh" groundwater on top of deep seated brackish to saline paleowater [11]. The "fresh" groundwater, with a low $\mathrm{Cl} / \mathrm{Br}$ ratio and high stable isotope content, is considered to be derived from local precipitation during relatively warm and humid climatic conditions with high evaporation losses, without significant contributions from evaporite dissolution [11,29]. The brackish to saline paleowater, with a high $\mathrm{Cl} / \mathrm{Br}$ ratio and low stable isotope content, is considered to be derived from rainwater that dissolved evaporitic rock during relatively cold climatic conditions with less evaporation losses [11,29].

The following parameters follow the salinity (TDS) increase with depth: $\mathrm{EC}, \mathrm{Cl}, \mathrm{SO}_{4}, \mathrm{NO}_{3}, \mathrm{Na}$, $\mathrm{Fe}, \mathrm{Mn}, \mathrm{Al}, \mathrm{B}, \mathrm{Br}, \mathrm{Cr}, \mathrm{Cr}(\mathrm{VI}), \mathrm{Mo}, \mathrm{Ni}, \mathrm{Sr}$ and $\mathrm{Cl} / \mathrm{Br}$ ratio, whereas $\mathrm{HCO}_{3}, \mathrm{Ba}$ and $\mathrm{Ca} / \mathrm{Mg}$ ratio decline with depth (Table 2). All groundwater is (sub)oxic (containing little $\mathrm{O}_{2}$ and much $\mathrm{NO}_{3}$ ), more or less in equilibrium with calcite and dolomite (as expected on the basis of geochemistry), slightly undersaturated with respect to barite, and (strongly) undersaturated with respect to fluorite and gypsum (base of layer e excluded where near equilibrium with gypsum).

The current mean-annual rainfall of 40-60 mm/year [30] would be sufficient to sustain natural recharge by local precipitation at a rate of $\sim 7.6$ [11] or $11 \mathrm{~mm} /$ year [8]. Tritium data on samples taken close to the groundwater table, stable isotope data, fluoro-chlorinated hydrocarbons and reaction patterns of the groundwater table to recharge events confirm that recharge of groundwater is actually taking place [8].

Between well fields A, B and C some differences exist [23]. Well field B is the most saline at all depth levels. Well field $C$ is the least saline and most homogeneous of all. Well field A forms an intermediate, and is therefore taken as a representative for the whole plant. 
Table 1. Simplified geochemical stratification as derived from [23]. BOM = bulk organic material; CEC = Cation Exchange Capacity.

\begin{tabular}{|c|c|c|c|c|c|c|c|c|c|c|c|c|c|}
\hline \multirow{2}{*}{$\begin{array}{c}\text { Layer } \\
\text { No. }\end{array}$} & \multirow{2}{*}{$\begin{array}{c}\text { Top m } \\
\text { ASL }\end{array}$} & \multirow{2}{*}{$\begin{array}{c}\text { Base m } \\
\text { ASL }\end{array}$} & Quartz & Calcite & Dolomite & Feldspar & Clay Min. & Others & BOM & Gypsum & \multirow{2}{*}{$\begin{array}{l}\text { Apatite } \\
\mathrm{mg} / \mathrm{kg}\end{array}$} & \multirow{2}{*}{$\mathrm{pH}-\mathrm{H}_{2} \mathrm{O}$} & \multirow{2}{*}{$\begin{array}{c}\mathrm{CEC} \\
\mathrm{meq} / \mathrm{kg}\end{array}$} \\
\hline & & & \multicolumn{8}{|c|}{$\%$ d.w. } & & & \\
\hline $\mathrm{A}$ & 140 & 96 & 67.8 & 10.3 & 4.0 & 10.6 & 4.0 & 1.3 & 1.9 & $<0.1$ & 0 & 8.10 & 61.3 \\
\hline $\mathrm{B}$ & 96 & 80 & 83.0 & 2.9 & 2.3 & 9.2 & 1.5 & 1.7 & 0.5 & $<0.1$ & 123 & 8.12 & 19.0 \\
\hline $\mathrm{C}$ & 80 & 62 & 71.8 & 6.2 & 2.5 & 10.6 & 1.6 & 1.7 & 0.9 & $<0.1$ & 154 & 8.18 & 28.1 \\
\hline $\mathrm{D}$ & 62 & 56 & 47.0 & 19.9 & 18.3 & 6.0 & 18.2 & 1.3 & 0.5 & $<0.1$ & 956 & 8.00 & 136.7 \\
\hline $\mathrm{E}$ & 56 & -14 & 54.6 & 13.9 & 12.8 & 5.4 & 17.1 & 1.6 & 1.6 & 0.1 & 83 & 7.89 & 146.6 \\
\hline $\mathrm{F}$ & -14 & $<-40$ & 0.9 & 16.6 & 80.1 & 0.0 & 0.2 & 6.9 & 1.8 & 2.7 & 0 & 7.90 & 31.5 \\
\hline
\end{tabular}


Table 2. Simplified chemical stratification of the native groundwater, averaged over both pilot and ABC plant areas. Aquifer 1 = layers a-c; Aquitard 1 = layer d; Aquifer 2 = layer e. Abu Dhabi drinking water standards according to [13], WHO guidelines according to [31], both with red numbers for parameters considered at risk during ASR recovery. All samples showed: $\mathrm{Ag}<1, \mathrm{Be}<0.1, \mathrm{~Pb}<5 \mu \mathrm{g} / \mathrm{L}$.

\begin{tabular}{|c|c|c|c|c|c|c|c|c|c|c|}
\hline \multirow{3}{*}{ कू } & \multicolumn{2}{|c|}{ Layer \# Figure 5} & \multirow{3}{*}{$\begin{array}{c}a \\
140 \\
96\end{array}$} & \multirow{3}{*}{\begin{tabular}{|l}
$\mathrm{b}$ \\
96 \\
80
\end{tabular}} & \multirow{3}{*}{$\begin{array}{c}c \\
80 \\
62\end{array}$} & \multirow{3}{*}{$\begin{array}{l}\mathrm{d} \\
62 \\
56\end{array}$} & \multirow{3}{*}{$\begin{array}{c}\text { e-Top } \\
56 \\
35\end{array}$} & \multirow{3}{*}{$\begin{array}{c}\text { e-Base } \\
35 \\
-14\end{array}$} & \multirow{3}{*}{$\begin{array}{l}\text { Abu Dh. } \\
\text { Drinking w. } \\
\text { Standard }\end{array}$} & \multirow{3}{*}{$\begin{array}{c}\text { WHO } \\
2011 \\
\text { Guidelines }\end{array}$} \\
\hline & Denth & $\mathbf{m} A \mathbf{S I}$ & & & & & & & & \\
\hline & Deptiा & III ASL & & & & & & & & \\
\hline \multirow{5}{*}{ 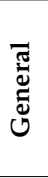 } & $\mathrm{O}_{2}$ & $\mathrm{mg} / \mathrm{L}$ & 0.9 & 2.0 & 2.2 & 2.3 & 2.5 & 0.0 & $>2$ & \\
\hline & Temp. & ${ }^{\circ} \mathrm{C}$ & 34.0 & 34.1 & 34.5 & 34.5 & 34.8 & 31.0 & & \\
\hline & $\mathrm{EC} 20^{\circ} \mathrm{C}$ & $\mu \mathrm{S} / \mathrm{cm}$ & 969 & 1180 & 2132 & 4095 & 5650 & 17,647 & 1600 & \\
\hline & TDS & $\mathrm{mg} / \mathrm{L}$ & 682 & 803 & 1545 & 2957 & 4042 & 13,288 & 1000 & \\
\hline & $\mathrm{pH}$ & lab & 7.83 & 8.25 & 8.09 & 7.92 & 7.94 & 7.40 & $7-9.2$ & \\
\hline \multirow{15}{*}{ 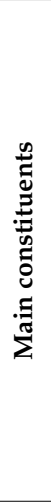 } & $\mathrm{Cl}$ & & 187 & 233 & 396 & 978 & 1506 & 5500 & 250 & \\
\hline & $\mathrm{SO}_{4}$ & & 147 & 152 & 397 & 702 & 844 & 3137 & 250 & \\
\hline & $\mathrm{HCO}_{3}$ & & 81 & 101 & 154 & 148 & 144 & 39 & $>60$ & \\
\hline & $\mathrm{NO}_{3}$ & & 25.0 & 30.8 & 37.4 & 41.7 & 42.6 & 96.0 & 50 & 50 \\
\hline & $\mathrm{PO}_{4}$ & & 0.022 & 0.034 & 0.029 & 0.028 & 0.030 & 0.015 & 2.2 & \\
\hline & F & & 1.29 & 1.50 & 3.61 & 3.29 & 2.39 & 0.75 & 1.5 & 1.5 \\
\hline & $\mathrm{Na}$ & & 141 & 209 & 466 & 877 & 1204 & 3238 & 150 & \\
\hline & K & $\mathrm{mg} / \mathrm{L}$ & 12.9 & 11.7 & 11.5 & 15.8 & 18.5 & 83.7 & 12 & \\
\hline & $\mathrm{Ca}$ & & 41.7 & 26.2 & 29.8 & 107.3 & 174.8 & 821.0 & 80 & \\
\hline & $\mathrm{Mg}$ & & 10.7 & 7.0 & 11.2 & 41.1 & 67.0 & 340.0 & 30 & \\
\hline & $\mathrm{Fe}$ & & 0.005 & 0.023 & 0.022 & 0.012 & 0.019 & $<0.44$ & 0.2 & \\
\hline & $\mathrm{Mn}$ & & 0.004 & 0.008 & 0.008 & 0.020 & 0.037 & 0.030 & 0.4 & \\
\hline & $\mathrm{NH}_{4}$ & & 0.015 & 0.025 & 0.019 & 0.015 & 0.015 & 0.035 & 0.5 & \\
\hline & $\mathrm{SiO}_{2}$ & & 26.2 & 23.1 & 28.4 & 27.8 & 23.6 & 14.3 & & \\
\hline & $\mathrm{DOC}$ & & 0.3 & 1.0 & 0.6 & 1.5 & 2.6 & 5.3 & 1 & \\
\hline \multirow{20}{*}{ 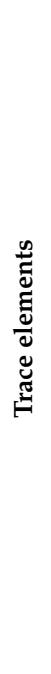 } & $\mathrm{Al}$ & \multirow{20}{*}{$\mu \mathrm{g} / \mathrm{L}$} & 3 & 19 & 19 & 19 & 23 & $<290$ & 200 & \\
\hline & As & & 2.1 & 11.4 & 9.6 & 6.0 & 4.7 & $<10$ & 10 & 10 \\
\hline & B & & 605 & 774 & 1113 & 1330 & 1421 & 1340 & 2400 & 2400 \\
\hline & $\mathrm{Ba}$ & & 40 & 38 & 31 & 33 & 36 & 23 & 700 & 700 \\
\hline & $\mathrm{Br}$ & & 579 & 668 & 788 & 762 & 767 & 301 & & \\
\hline & $\mathrm{Cd}$ & & 0.08 & 0.05 & 0.05 & 0.06 & 0.08 & $<10$ & 3 & 3 \\
\hline & Co & & 0.06 & 0.08 & 0.07 & 0.44 & 0.82 & & & \\
\hline & Cr-tot & & 52 & 87 & 115 & 129 & 123 & $<286$ & 50 & 50 \\
\hline & $\mathrm{Cr}(\mathrm{VI})$ & & 48 & 85 & 108 & 119 & 117 & & & \\
\hline & $\mathrm{Cu}$ & & 0.3 & 0.7 & 0.9 & 0.3 & 0.3 & $<1$ & 1000 & 2000 \\
\hline & $\mathrm{Hg}$ & & 0.02 & 0.23 & 0.13 & 0.02 & 0.04 & & 6 & 6 \\
\hline & Mo & & 6 & 11 & 39 & 47 & 39 & $<10$ & & \\
\hline & $\mathrm{Ni}$ & & 0.5 & 2.5 & 1.6 & 1.0 & 1.6 & & 70 & 70 \\
\hline & $\mathrm{Sb}$ & & $<1$ & 2.2 & 1.2 & $<1$ & $<1$ & & 20 & 20 \\
\hline & Se & & 3.2 & 3.2 & 3.3 & 4.1 & 5.2 & 17.0 & 40 & 40 \\
\hline & $\mathrm{Sr}$ & & 3485 & 2846 & 7381 & 8486 & 6573 & 1700 & & \\
\hline & $\mathrm{Ti}$ & & $<0.5$ & $<0.5$ & $<0.5$ & 0.6 & 0.7 & & & \\
\hline & $\mathrm{U}$ & & 0.6 & 0.7 & 3.0 & 3.1 & 3.1 & & & 30 \\
\hline & $\mathrm{V}$ & & 29 & 77 & 95 & 71 & 49 & $<10$ & & \\
\hline & $\mathrm{Zn}$ & & 3 & 16 & 7 & 2 & 2 & $<50$ & 5000 & \\
\hline \multirow{3}{*}{ 苞 } & $\mathrm{Cl} / \mathrm{Br}$ & & 323 & 348 & 503 & 1284 & 1963 & 18297 & & \\
\hline & $\mathrm{Ca} / \mathrm{Sr}$ & $\mathrm{mg} / \mathrm{L}$-basis & 12.0 & 9.2 & 4.0 & 12.6 & 26.6 & 482.9 & & \\
\hline & $\mathrm{Ca} / \mathrm{Mg}$ & & 3.9 & 3.8 & 2.7 & 2.6 & 2.6 & 2.4 & & \\
\hline \multirow{6}{*}{ 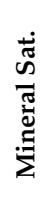 } & Barite & & -0.12 & -0.13 & -0.14 & -0.16 & -0.20 & -0.50 & & \\
\hline & Calcite & & -0.06 & 0.15 & 0.13 & 0.10 & 0.13 & -0.15 & & \\
\hline & Dolomite & Saturation & -0.26 & 0.18 & 0.30 & 0.29 & 0.39 & -0.15 & & \\
\hline & Fluorite & Index & -0.82 & -0.95 & -0.29 & -0.37 & -0.68 & -0.82 & & \\
\hline & Gypsum & & -1.72 & -1.96 & -1.70 & -1.42 & -1.43 & -0.02 & & \\
\hline & TIC & $\mathrm{mmol} / \mathrm{L}$ & 1.38 & 1.71 & 2.59 & 2.51 & 2.43 & 0.68 & & \\
\hline
\end{tabular}




\section{Results of Sampling Campaign in August 2014}

The sampling campaign of 3-7 August 72014 revealed [23] that there was only limited bias in the 2003-2013 hydrochemical data set of well fields A, B and C, and that practically all (>95\%) of dissolved Cr consists indeed of $\mathrm{Cr}(\mathrm{VI})$.

The following bias was deduced for the large data set 2003-2013: $\mathrm{O}_{2}$ concentrations for all monitoring wells were too high due to oxygenation, and suspended fines raised the concentrations of $\mathrm{PO}_{4}, \mathrm{Fe}, \mathrm{Mn}, \mathrm{NH}_{4}, \mathrm{Al}$, and possibly also $\mathrm{Zn}$ in many samples. In addition, the minimum detection limits (MDLs) could be lowered for $\mathrm{Cd}, \mathrm{Hg}, \mathrm{Ni}$, and $\mathrm{Sb}$. All hydrochemical data presented here have been corrected for the demonstrated bias, where possible.

\section{Results of Pilot}

The available monitoring data at the pilot in 2003-2004 and 2014 (some of which are in Table 3) reveal among others the following quality changes of DSW in the aquifer:

- There are hardly any changes of $\mathrm{O}_{2}, \mathrm{Cl}, \mathrm{SO}_{4}, \mathrm{HCO}_{3}, \mathrm{TIC}, \mathrm{NO}_{3}$ and $\mathrm{NH}_{4}$, even after six years of storage. This indicates that redox reactions were practically nonexistent, and carbonates (calcite and dolomite) hardly dissolved or precipitated.

- A small TDS increase (20-30 mg/L) by dissolution of mainly $\mathrm{SiO}_{2}, \mathrm{~K}$ and possibly Mg. Carbonate dissolution was noticed only where a very strong $\mathrm{Ca} / \mathrm{Na}$ exchange was taking place (see next point).

- $\mathrm{Ca} / \mathrm{Na}$ exchange in which Ca concentrations declined and Na increased was observed. This was especially important for samples close to the DSW intrusion front and typical for fresh water intrusion.

- Mobilization of the trace elements As, B, Ba, F, Cr, Sr and V from the aquifer, through desorption and/or mineral dissolution was observed. The strongest and most persistent increase is noticed for $\mathrm{Sr}$, which does not exactly match Ca behavior, so that another mineral could be the source. Of the trace elements mentioned, Ba shows the smallest mobilization, whereas As, F and Cr show a significant leaching by DSW, which is also important from a drinking water quality perspective.

- Immobilization of $\mathrm{PO}_{4}, \mathrm{Al}, \mathrm{Cu}, \mathrm{Fe}$ and $\mathrm{Ni}$ during aquifer passage was mainly by sorption of $\mathrm{PO}_{4}$, $\mathrm{Cu}$ and $\mathrm{Ni}$, and filtration of suspended colloidal particles of $\mathrm{Al}$ and $\mathrm{Fe}$.

- Calculated mineral saturation indices show that the infiltrated water is more or less in equilibrium with calcite and dolomite as expected. The values for gypsum, barite and fluorite indicate a strong undersaturation.

These changes were subsequently plotted against dimensionless time parameter PV (Equation (1)), as shown for a selection of constituents in Figure 9. The resulting patterns were translated into leaching and retardation factors and semi-permanent concentration changes (Table 4). These observations assisted in fine-tuning the EL model, which is partly based on both calculated and observed values of $\mathrm{L}, \mathrm{R}$ and $\mathrm{DC}$. 
Table 3. Overview of water quality at the pilot basin recharge scheme in 2003-2004 and in August 2014. The samples taken in 2014 refer to a second recharge trial in 2008 at the same pilot plant, and therefore represent DSW after six years of aquifer storage. DSW infiltrated in 2008 (not shown here) deviates only slightly from DSW sampled in 2014.

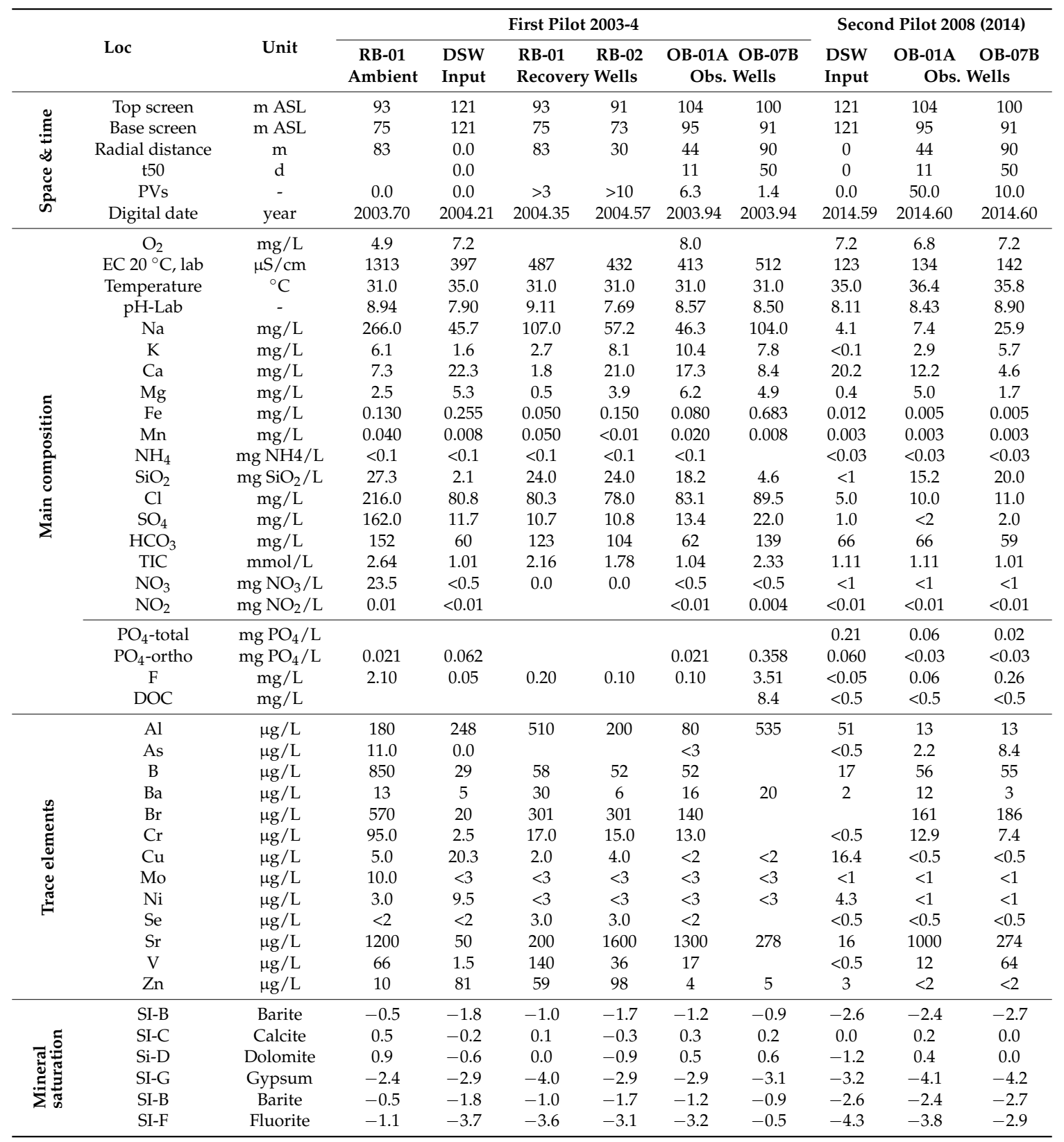



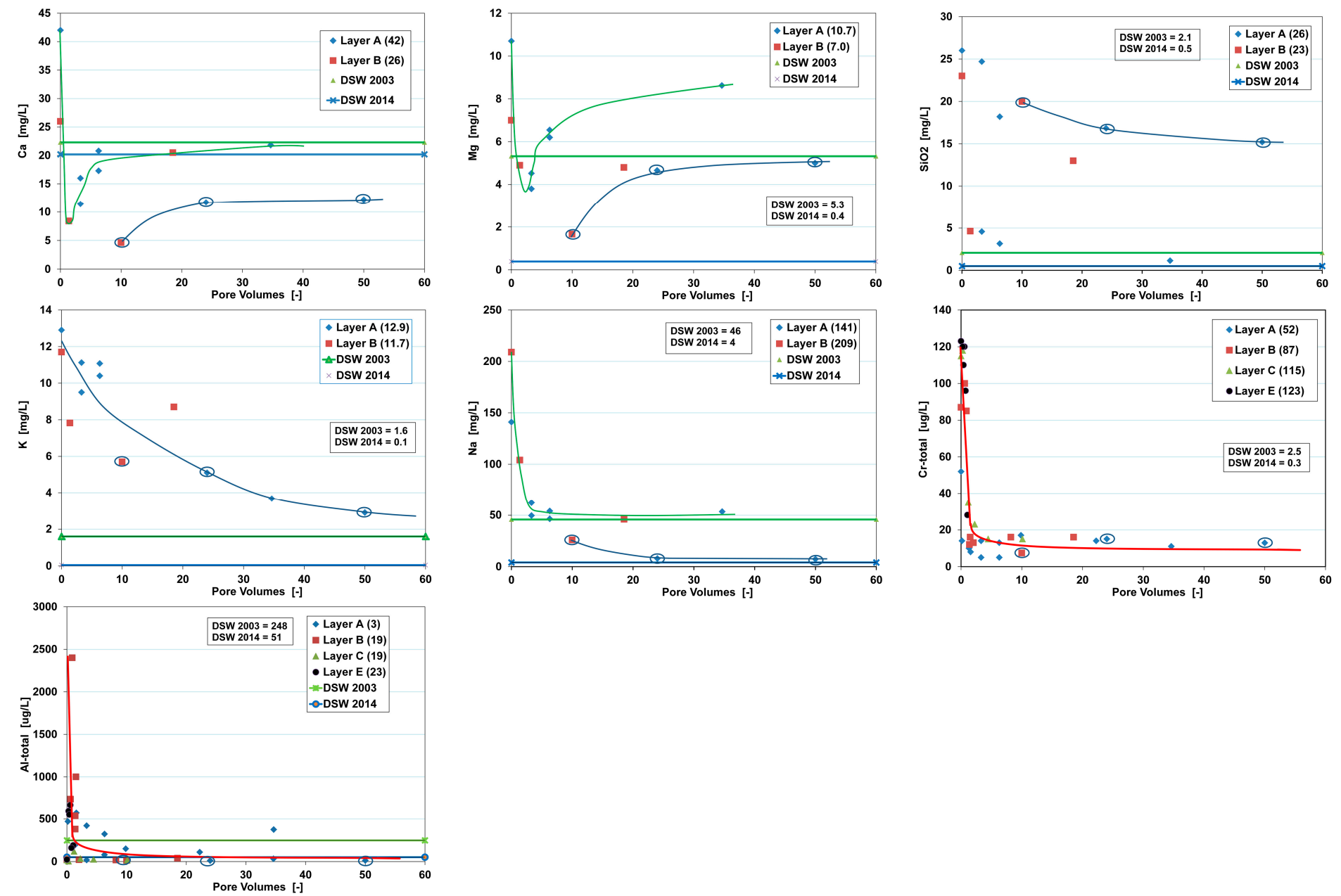

Figure 9. Concentration of selected constituents during and long after breakthrough of DSW in aquifer layers A, B, C and E in the pilot basin recharge scheme, with best fitting lines for all data points or for the data of 2003-2004 and 2014, separately. Mean concentrations in DSW in 2003 and 2014 and in native groundwater of the 2-4 aquifer layers (in legend, within brackets) are indicated. The three encircled observation points in the plot were sampled in August 2014 (after six-year storage), the others were sampled in 2003-2004. Note that samples with $>3$ pore volumes consist of 100\% DSW! 
The plots in Figure 9 show the observed concentration trends for selected constituents as function of the dimensionless time parameter "pore volume" (PV). The following classification of elements with similar behavior can be made on the basis of their concentration/PV-plot.

- $\quad \mathrm{Ca}, \mathrm{Mg}$ and $\mathrm{Sr}$ (Ca and Mg shown in Figure 9) concentrations start low and with increasing PVs rise to an asymptotic value. All 2014 data plot below those of 2003-2004, which is partly explained by the lower DSW input in 2008. Only Ca and Mg show an initial concentration below DSW input, which is probably linked to Na exchange, with Ca developing an asymptotic value at or below DSW input. Contrary, Mg and Sr approach an asymptotic value little (Mg) or far (Sr) above DSW input. Obviously, $\mathrm{Mg}$ and even more so $\mathrm{Sr}$ are dissolved from the aquifer, and $\mathrm{Ca}$ is not. Sources of $\mathrm{Mg}$ and $\mathrm{Sr}$ could be dolomite and/or silicate minerals.

- $\mathrm{SiO}_{2}, \mathrm{~K}$ and $\mathrm{V}$ concentrations $\left(\mathrm{SiO}_{2}\right.$ and $\mathrm{K}$ shown in Figure 9) decline in an exponential way, but relatively slowly compared to the next group, and the low concentration asymptote is also relatively high and in most cases far above DSW input. This suggests that these elements are initially desorbed and that later on they could be dissolving from the aquifer, possibly from quartz $\left(\mathrm{SiO}_{2}\right)$, K-feldspar $\left(\mathrm{K}\right.$ and $\left.\mathrm{SiO}_{2}\right)$ or for instance pyroxenes $\left(\mathrm{SiO}_{2}\right.$ and $\left.\mathrm{V}\right)$. A long storage time yields much higher concentrations for $\mathrm{SiO}_{2}$, pointing at slow dissolution kinetics. Vanadium is likely present as $\mathrm{VO}_{4}{ }^{3-}$, which could desorb from iron (hydr)oxide coatings.

- $\quad \mathrm{Na}, \mathrm{As}, \mathrm{B}, \mathrm{Cr}, \mathrm{F}$ and $\mathrm{Mo}$ ( $\mathrm{Na}$ and $\mathrm{Cr}$ shown in Figure 9) concentrations also decline in an exponential way, but much more rapidly than the previous group. The low concentration asymptote is relatively high and in any case significantly above DSW input, especially for As, B and $\mathrm{Cr}$. The asymptote approaches DSW input better for $\mathrm{Na}, \mathrm{F}$ and Mo. This suggests that all these elements are very rapidly desorbed and that later on especially As, B and Cr could be steadily dissolving from the aquifer matrix. Except for $\mathrm{Na}$ and $\mathrm{B}\left(\mathrm{as}_{3} \mathrm{BO}_{3}\right)$, this group is composed of anions, $\mathrm{As}$ as $\mathrm{AsO}_{4}{ }^{3-}, \mathrm{Cr}$ as $\mathrm{CrO}_{4}{ }^{2-}, \mathrm{F}$ as $\mathrm{F}^{-}$and $\mathrm{Mo}$ as $\mathrm{MoO}_{4}{ }^{2-}$. The source mineral of chromate and vanadate could be pyroxenes [23].

- Al, Fe and Ni concentrations (Al shown in Figure 9) decline in an exponential way, approximately as rapidly as the previous group. Their concentration seems to be dictated by colloidal particles that become initially mobilized. On the one hand, lack of filtration may have contributed to this. On the other hand, it is well known [32], that clay minerals in aquifers tend to be mobilized by deflocculation when the sodium adsorption ratio (SAR) of the infiltration water and of the native groundwater is high, their salinity low, the clay mineral content high, and the dominant type of clay minerals unfavorable (smectite $>$ illite $>$ kaolinite). The SAR value of the native groundwater seems to be more important than the one of the infiltration water. With SAR values of $\sim 20$, the risk of mechanical clogging of the aquifer when the particles strand in the pore necks is relatively high. This risk is estimated higher in aquifer layer $C$ than in A and B because SAR of native groundwater is higher and permeability is lower.

In Table 4, the estimated retardation (R) or leach factors (L) as derived from the PV-plots (Figure 9) are listed, together with the estimated (semi)permanent concentration increase (DC). 
Table 4. Interpretation of water quality observations at the pilot, in terms of retardation factor (R), Leach factor (L) and (semi)permanent concentration change after break-through $(\Delta C)$.

\begin{tabular}{|c|c|c|c|c|c|c|c|c|c|}
\hline \multirow{2}{*}{ Parameter } & \multirow{2}{*}{$\mathbf{L}$} & \multirow{2}{*}{$\mathbf{R}$} & \multicolumn{2}{|c|}{$\Delta \mathrm{C}[\mathrm{mg} / \mathrm{L}]$} & \multirow{2}{*}{ Parameter } & \multirow{2}{*}{$\mathbf{L}$} & \multirow{2}{*}{$\mathbf{R}$} & \multicolumn{2}{|c|}{$\Delta \mathrm{C}[\mathrm{ug} / \mathrm{L}]$} \\
\hline & & & 2003-4 & 2014 & & & & 2003-4 & 2014 \\
\hline $\mathrm{Na}$ & $1.5-2$ & - & 3 & 3.5 & $\mathrm{~F}$ & $1.5-2$ & - & 0.2 & 0.04 \\
\hline K & 20 & - & 3 & 3 & $\mathrm{Al}$ & 1.5 & - & -130 & -39 \\
\hline $\mathrm{Ca}$ & - & 3.5 & 0 & -8 & As & 3 & - & 1 & 2 \\
\hline $\mathrm{Mg}$ & - & 3 & 3.3 & 4.5 & B & 2 & - & 10 & 30 \\
\hline $\mathrm{Fe}$ & 2 & - & 0 & 0 & $\mathrm{Ba}$ & - & - & 10 & 10 \\
\hline $\mathrm{SiO}_{2}$ & $2-4$ & - & 0.6 & 14.5 & $\mathrm{Cr}$ & $1.5-2$ & - & 10 & 13 \\
\hline $\mathrm{Cl}$ & 1 & - & 0 & 0 & Mo & 1.5 & - & 0 & 0 \\
\hline $\mathrm{SO}_{4}$ & 1 & - & 0 & 0 & $\mathrm{Ni}$ & 1.5 & - & -8 & -4 \\
\hline $\mathrm{HCO}_{3}$ & 1 & - & 0 & 0 & $\mathrm{Sr}$ & - & 3.5 & 1600 & 984 \\
\hline $\mathrm{NO}_{3}$ & 1 & - & 0 & 0 & $\mathrm{~V}$ & 5 & - & 10 & 11 \\
\hline $\mathrm{PO}_{4}-\mathrm{O}$ & - & - & -0.04 & -0.05 & $\mathrm{Zn}$ & - & - & -60 & -1.5 \\
\hline
\end{tabular}

It can be concluded that those parameters that could cause problems with drinking water standards (Table 2), such as EC, TDS, $\mathrm{Na}, \mathrm{Cl}, \mathrm{SO}_{4}, \mathrm{~F}$, As and $\mathrm{Cr}$, are swiftly leached out from the aquifer, namely most of them within 1-3 PVs. The leach factor for $\mathrm{Cr}$ corresponds well with the chromate retardation factor as observed in a column dosage experiment [33], and with observations elsewhere [34,35].

The (semi)permanent concentration increases can, in general, be attributed to mineral dissolution or prolonged desorption from low permeability but high concentration pockets within the aquifer. The significant $\mathrm{Ca}$ decrease and $M g$ increase during the six-year storage period could point at dedolomitization, in which possibly also $\mathrm{Sr}^{2+}$ is involved:

$$
(Y+Z) \mathrm{Ca}^{2+}+\mathrm{Ca}_{X} \mathrm{Mg}_{Y} \mathrm{Sr}_{Z} \mathrm{CO}_{3} \leftrightarrow \mathrm{CaCO}_{3}+Y \mathrm{Mg}^{2+}+\mathrm{ZSr}^{2+}
$$

where $X+Y+Z=1$, possibly with $M g=0.38$ and $S r=0.02$.

The relatively strong increase for $\mathrm{SiO}_{2}$ during the six-year storage period could at least partly be explained by quartz dissolution at the relatively high water temperatures $\left(35^{\circ} \mathrm{C}\right)$. The following relation by [36] can be used to predict quartz solubility at temperatures $0-200^{\circ} \mathrm{C}$, yielding $14.3 \mathrm{mg} / \mathrm{L}$ at $35^{\circ} \mathrm{C}$ :

$$
\mathrm{SiO}_{2}=10^{4.83-\frac{1132}{\operatorname{temp+273.15}}}
$$

\section{Results of Predicting the Quality of Recovered Water}

\subsection{Model Settings}

The SWSR ASR system was modeled for just one of three recharge basins, assuming this to be representative for all three basins. The applied hydrogeological and geochemical stratification of the aquifer system into five layers follows the information given in Section 3. The low TDS DSW was selected as constant input to the recharge basin. Its quality is shown in Table 3.

The travel times to all recovery wells (condensed into one well per ring) and flux contributions from each aquifer layer to the well discharge, were calculated as indicated in Section 2.7. The combination of travel times leads to the so-called response curve of the whole well field. This is defined as the cumulative frequency distribution of underground travel times from the recharge basin to the wells during infiltration. The resulting response curve is shown in Figure 10.

Water quality changes in the recharge basin were completely ignored, because of exclosure from both sunlight and direct atmospheric contact, the high quality of DSW and the expected ultralow concentration of suspended solids. The formation of bottom muds in the basin was excluded. The complete lack of redox reactions necessitated the setting of the reactivity of bulk organic material at zero. 


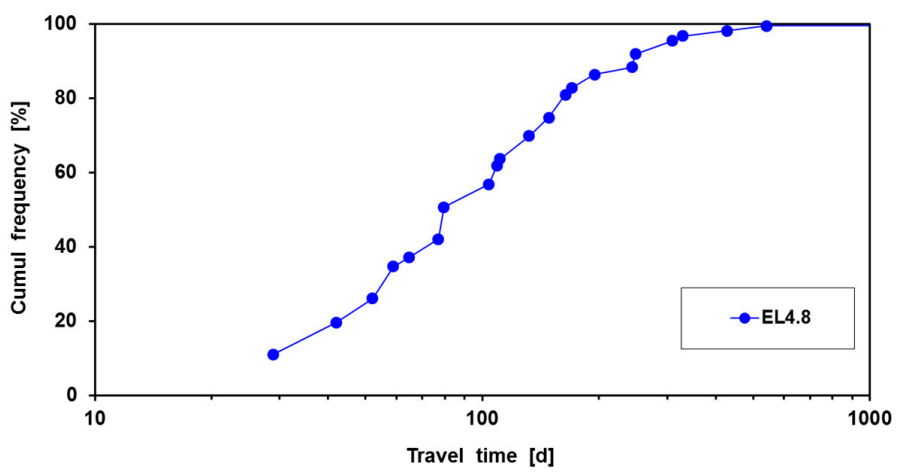

Figure 10. The cumulative frequency distribution of travel times from the recharge basin to the schematized seven recovery wells around it. Flowlines in aquifer layers D and $E$ are excluded because of their very low contribution (together $0.42 \%$ ).

\subsection{Quality Evolution during Nonstop Infiltration}

If the infiltration via one of the recharge basins of the SWSR facility would last for 100 years without interruption, and the recovery wells would periodically pump out a water sample during this period varying between 0.1 and 100 years, then the abstracted water quality would be as predicted in Table 5. This table also shows the quality of DSW prior to infiltration and of native groundwater as abstracted by all $A B C$ recovery wells.

Many things can be concluded from this table, because the recovered water quality also covers those moments that are representative for the $90 \mathrm{~d}$ recovery with or without drift. That aspect follows in Section 6.3.

Here, it is concluded that continued flushing leads to an initially fast and then slow elution of native groundwater, a significant leaching of the trace elements $\mathrm{As}, \mathrm{B}, \mathrm{Ba}, \mathrm{Cr}, \mathrm{F}$ and $\mathrm{Sr}$, and a slow breakthrough of $\mathrm{Cu}, \mathrm{Ni}$ and $\mathrm{Zn}$ which show higher concentration levels in DSW than in native groundwater. For selected elements, the breakthrough or leaching curves have been plotted in Figure 11. The bulk of changes clearly happens during the first year when the native groundwater is displaced.

The predicted water quality after 0.27 year is also representative of water quality after $90 \mathrm{~d}$ recovery following 10 years of lateral drift after $824 \mathrm{~d}$ of DSW infiltration. The quality after 0.74 year is as the one after 0.27 year, but without lateral drift (thus, with direct recovery). The quality after 2.26 years is the water that is recovered on the first day after $824 \mathrm{~d}$ of DSW infiltration.
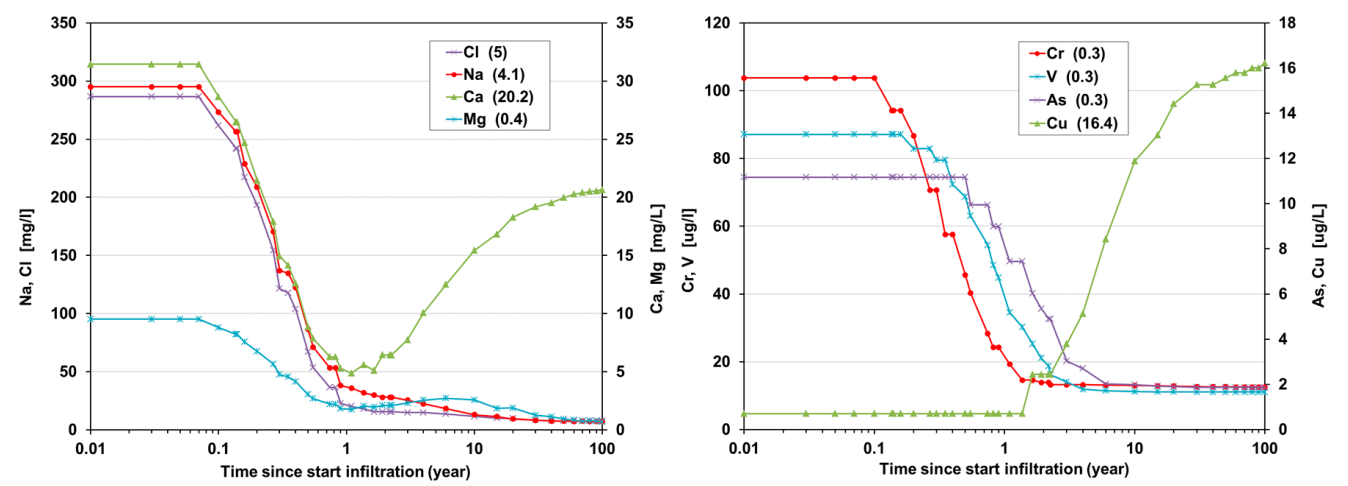

Figure 11. With EL calculated concentration trends of selected main constituents and trace elements in groundwater that flowed past all recovery wells during nonstop infiltration via a recharge basin. 
Table 5. Overview of water quality in the SWSR ASR scheme, showing input DSW (Desalinated Seawater), mean native groundwater (when sampled by all wells) and groundwater as if it were periodically sampled after 0.1 to 100 years during nonstop DSW infiltration.

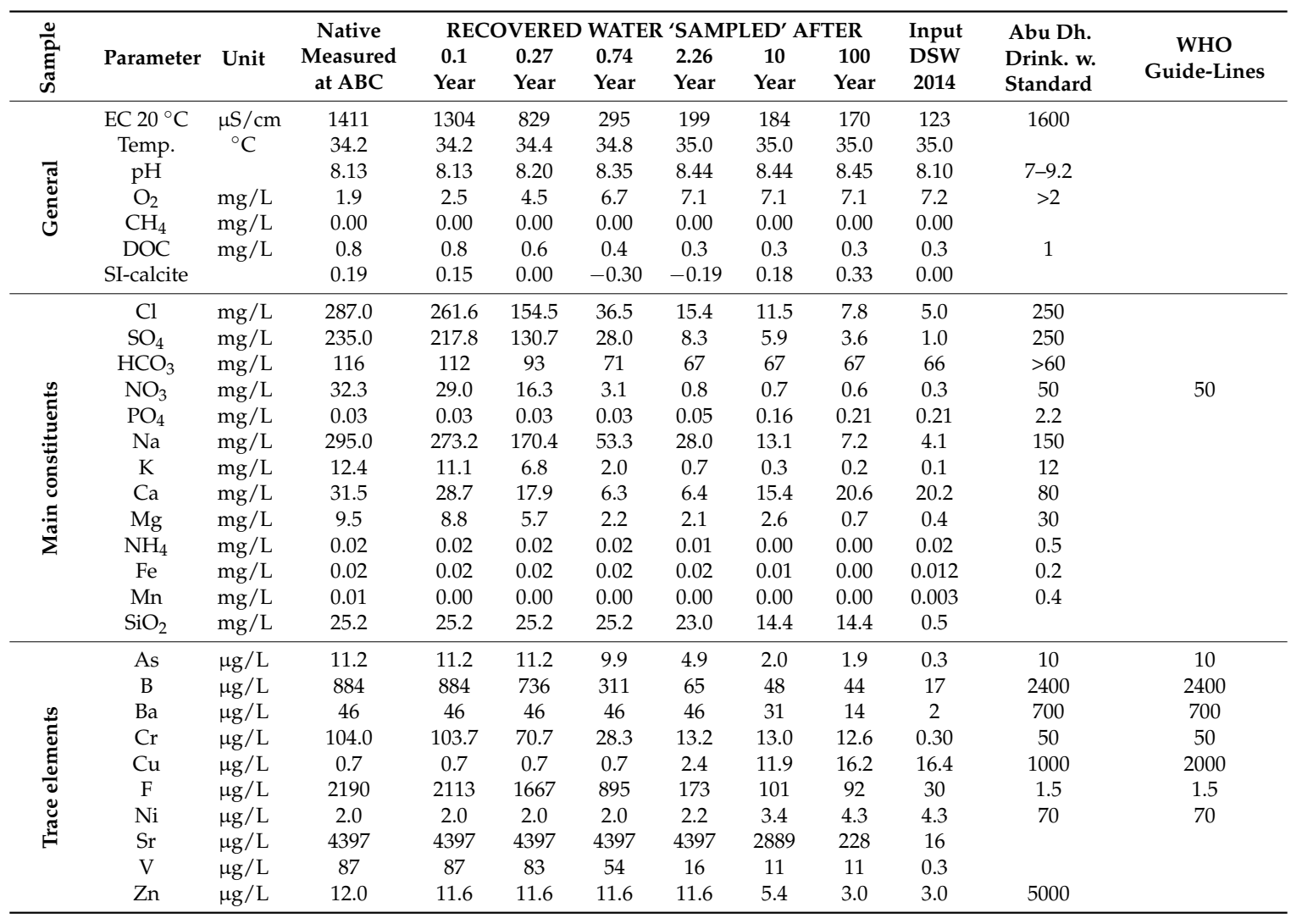

\subsection{Quality Evolution during Recovery}

The standard EL output list had to be elaborated, as indicated in Figure 7, in order to depict the water quality evolution during the $90 \mathrm{~d}$ of recovery (with or without 10 years standstill before). The result is shown for selected elements ( $\mathrm{Na}, \mathrm{Cl}, \mathrm{NO}_{3}, \mathrm{As}, \mathrm{Cr}$ and $\left.\mathrm{F}\right)$, TDS and the contribution of DSW in Figure 12, and for many more water quality parameters in Table 5.

It is concluded that TDS and the concentration of most dissolved constituents slowly rise, while the percentage of DSW slowly decreases during progressive recovery. The main reason of this worsening water quality is the admixing of native groundwater. Without a preceding 10-year storage phase and thus practically without bubble drift, recovered water quality complies with the UAE drinking water standards (Table 2), with only As approximating the maximum permissible concentration near the end.

Ten years of storage with bubble drift have a more negative impact on water quality, as expected. This becomes manifest only halfway during the $90 \mathrm{~d}$ recovery phase (Figure 12), and starts to become critical in between 80 and $90 \mathrm{~d}$, especially regarding $\mathrm{Na}, \mathrm{As}, \mathrm{Cr}$ and $\mathrm{F}$. These constituents are predicted to exceed the drinking water MPCs: Na 170 (MPC 150 mg/L), As 11.2 (MPC $10 \mathrm{ug} / \mathrm{L}$ ), Cr 70.7 (MPC $50 \mathrm{ug} / \mathrm{L}$ ) and F 1.67 (MPC $1.5 \mathrm{mg} / \mathrm{L}$ ). 

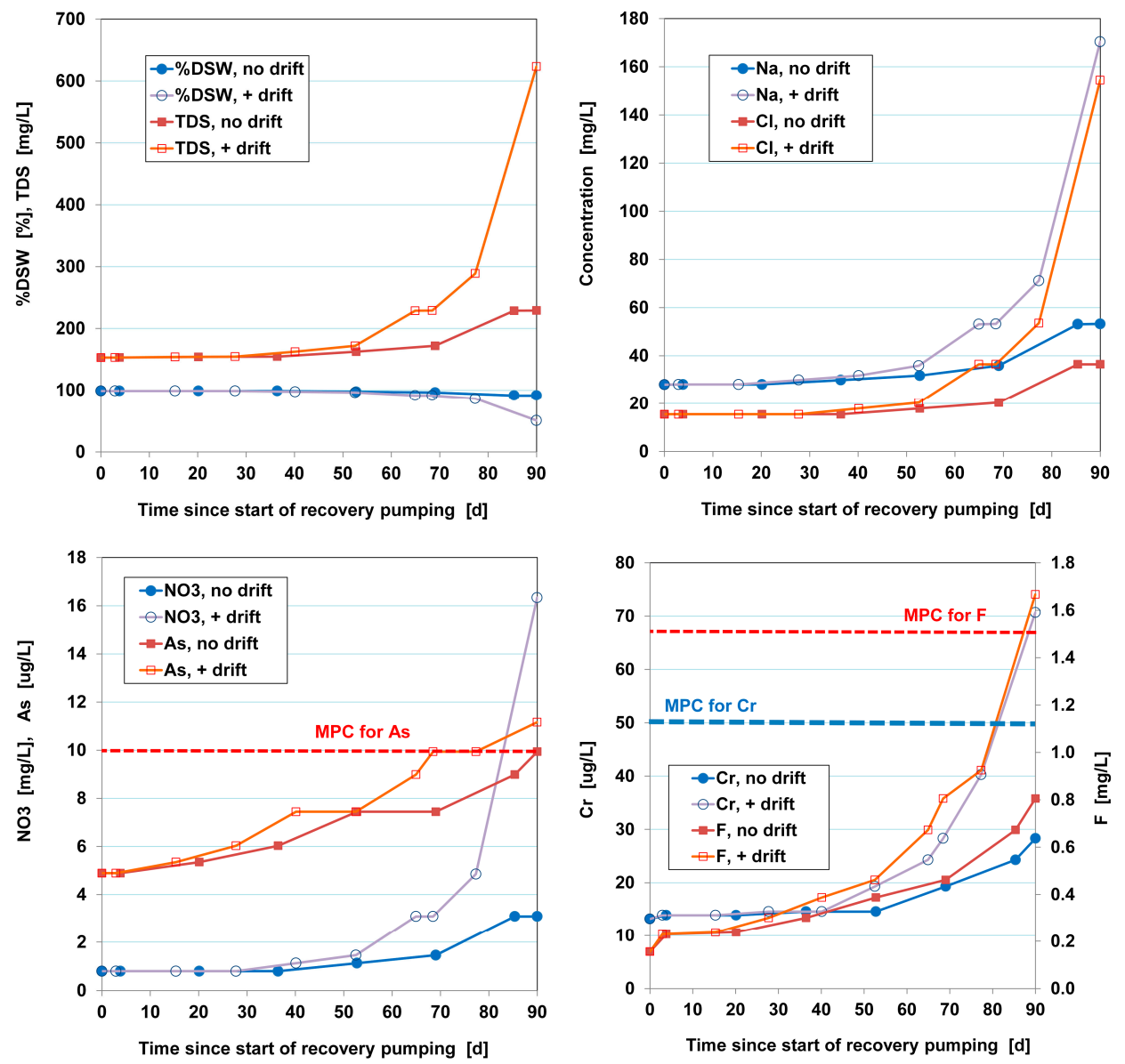

Figure 12. With EL calculated concentration trends of selected elements dissolved in groundwater that is recovered from the DSW basin infiltration system after $824 \mathrm{~d}$ of recharge, without bubble drift (no storage phase) and with bubble drift (with 10 years of standstill prior to recovery). MPC = Maximum Permissible Concentration by Abu Dhabi's drinking water standard.

\section{Discussion}

The relatively simple modeling approach as presented in Section 2.7 and applied in Section 6, strongly relies on: (i) observations done during trials in the pilot area; and (ii) reversibility of the predicted water quality evolution during forward (infiltration) mode. This means that complications due to shorter or longer detention times in the aquifer (during storage and recovery) or due to processes like biofouling of the basin proximal zone should not occur.

Problematic deviations from our predictions could arise, when the relatively high recovery rate (six times higher than the infiltration rate) would provoke serious upconing of brackish to saline groundwater from Aquifer 2, or when pockets of lower permeability in aquifer 1 would deliver more of their interstitial, low quality groundwater. A more dedicated spatial model, in which density effects and reactive transport (e.g., [19]) are combined, is needed to assess the potential impact of these processes.

There are other important questions still to answer, probably necessitating column studies and prolonged field monitoring during operation. The first question is: Which mineral sources could be responsible for the remarkable, semipermanent background mobilization of especially $\mathrm{Cr}$, $\mathrm{V}$, As and $\mathrm{Sr}$, and how can this mobilization be mitigated? The second is whether clay minerals will deflocculate upon flushing of the target aquifer, and thereby clog it. There are weak signs that this might have happened to a minor degree during the pilot. The risk of clay mobilization will be higher during the 
operational phase, because still lower TDS infiltration water (DSW) will be used, and the ABC area contains some higher salinity subareas than the pilot area.

\section{Conclusions}

In this paper, we present the peculiar characteristics of an eolian-fluvial, (sub)oxic, calcareous sand(stone) aquifer system in a desert environment, the unique water quality changes during an ASR pilot including a six-year storage phase, and a relatively simple modeling approach to rapidly predict water quality of the recovered water, which is to be distributed without treatment.

In the applied Easy-Leacher model, pilot observations on retardation, leaching and (semi)permanent concentration changes are combined with a strong schematization of the complex basin-ASR system, groundwater flow (including bubble drift) and hydrogeochemical processes.

The hydrogeochemical simplifications are justified by the low reactivity of the aquifer, which is explained by the very low solute content of desalinated seawater (DSW), the infiltration of (sub)oxic DSW into an already (sub)oxic aquifer (thus, preventing redox reactions), a rapid leaching and, at high $\mathrm{pH}(7.8-8.5)$, high mobility of the problematic trace elements $\mathrm{Cr}\left(>95 \%\right.$ as $\left.\mathrm{CrO}_{4}{ }^{2-}\right), \mathrm{B}\left(\mathrm{as} \mathrm{H}_{3} \mathrm{BO}_{3}\right), \mathrm{F}$, $\mathrm{Mo}\left(\right.$ as $\left.\mathrm{MoO}_{4}{ }^{2-}\right)$, and $\mathrm{V}\left(\right.$ as $\mathrm{VO}_{4}{ }^{3-}$ ).

The pilot observations and modeling results demonstrate that recovered water is most likely complying with Abu Dhabi's drinking water standards in both studied ASR scenarios. Without preceding 10-year storage (and thus hardly any drift, but with replacement of native groundwater), recovered water quality is expected to comply with the drinking water standards after $824 \mathrm{~d}$ of infiltration, even beyond the $67 \%$ recovered in $90 \mathrm{~d}$ (up to $\sim 85 \%$ recovery). The same conclusions also hold for the modeled scenario with 10-year storage (and thus significant bubble drift), however not for 90 but for $80 \mathrm{~d}$. This means that the recovery efficiency will drop from $\sim 85$ to $60 \%$. After $80 \mathrm{~d}(60 \%$ recovered), MPC exceedances are then expected for: $\mathrm{Na}(20$ above $150 \mathrm{mg} / \mathrm{L})$, As (1 above $10 \mu \mathrm{g} / \mathrm{L}), \mathrm{Cr}(21$ above $50 \mu \mathrm{g} / \mathrm{L})$ and $\mathrm{F}(0.2$ above $1.5 \mathrm{mg} / \mathrm{L})$. The main reason for their exceedances is the admixing of native groundwater.

This prediction has contributed to the implementation of some adaptations to the current ASR scheme operational since May 2015. The injection rate was raised by $20 \%$, and during storage $568 \mathrm{~m}^{3} / \mathrm{d}$ will be infiltrated continuously during any storage period. By adjusting pumping schemes based on real time monitoring, the recovery efficiency can probably be maintained at about $80 \%$.

If drinking water standards would become more strict, as is currently discussed in the Netherlands regarding As (from 10 to $1 \mu \mathrm{g} / \mathrm{L}$ ) and $\mathrm{CrO}_{4}{ }^{2-}$ (from 50 to $0.3 \mu \mathrm{g} / \mathrm{L}$; [37]), then Abu Dhabi's drinking water standards will be exceeded in all modeled cases. This may be acceptable, however, during a short emergency situation after a calamity.

Potential risks of upconing of brackish/saline deep, native groundwater, aquifer clogging by clay mobilization and basin clogging were not addressed, and may necessitate further research.

Acknowledgments: This study was funded by the Environment Agency of Abu Dhabi (EAD). Figures 1-3 were kindly provided by GTZ-Dornier. George Koziorowski (GTZ) is acknowledged for sharing some of his water quality data and for valuable discussions. Anonymous reviewers helped to improve the text.

Author Contributions: Pieter J. Stuyfzand evaluated all existing data, developed and applied the ASR model for predicting future recovered water quality, and wrote the paper. Koen G. Zuurbier conducted the field campaign in 2014. Niels Hartog performed the PHREEQC-2 modeling. Ebel Smidt and Mohammed A. Dawoud formulated the framework for this research and guided all steps in conducting this research, contributed by supplying information and edited texts.

Conflicts of Interest: The authors declare no conflict of interest. 


\section{Abbreviations}

The following abbreviations are used in this manuscript:

$\Delta C$

$\Delta H / \Delta X$

$\Delta t_{B A C K-1}$

$\rho_{\mathrm{S}}$

ASL

ASR

BOM

BSL

BTC

CEC

DSW

$K_{d}$

$K_{h, N}$

$\mathrm{Li}$

MPC

MSL

$n$

$n_{N}$

ORP

(prod)

PV

$Q_{I N}$

$r$

$r_{552, N}$

(reac)

$R_{i}$

$r_{P}$

$r_{R}$

(solid)

$T$

$t_{50}$

TDS

$t_{i}$

$t_{I N F}$

$t_{N}$

TOC

$t_{V}$

$v_{B, N}$ (semi)permanent concentration change

mean regional hydraulic gradient in aquifer [-]

setback time without horizontal bubble drift [d]

density of solids of porous medium $[\mathrm{kg} / \mathrm{L}]$

above sea level

Aquifer Storage and Recovery

bulk organic material in aquifer

below sea level

break through curve

cation exchange capacity

desalinated seawater

distribution coefficient $[\mathrm{L} / \mathrm{kg}]$

horizontal hydraulic conductivity of layer $\mathrm{N}[\mathrm{m} / \mathrm{d}]$

leach factor for compound $i$

maximum permissible concentration

mean sea level

porosity [L/L]

porosity of layer $\mathrm{N} \mathrm{[-]}$

oxidation reduction potential

concentration of reaction product in fluid during leaching $[\mathrm{mmol} / \mathrm{L}]$

pore volume

mean infiltration rate $\left[\mathrm{m}^{3} / \mathrm{d}\right]$

radial distance from the basin center $[\mathrm{m}]$

radial distance in aquifer layer $\mathrm{N}$, to ASR well after $552 \mathrm{~d}$ recovery

concentration of reactant in flushing fluid [mmol/L]

retardation factor for compound $i$

reaction coefficient related to (prod) [-].

reaction coefficient related to (reac) [-]

content of reactive phase in aquifer $[\mathrm{mmol} / \mathrm{kg}$ dry weight]

transmissivity of the aquifer $\left[\mathrm{m}^{2} / \mathrm{d}\right]$

observed $50 \%$ breakthrough time of conservative tracer or calculated travel time

total dissolved solids

time for $\geq 90 \%$ break-through $\left(R_{i}\right)$ or $\geq 90 \%$ leaching $\left(L_{i}\right)$ or till equilibrium [days]

total infiltration period [d]

$50 \%$ break-through time in layer $\mathrm{N}[\mathrm{d}]$

total organic carbon

vertical travel time $[\mathrm{d}]$

horizontal bubble drift in layer $\mathrm{N}[\mathrm{m} / \mathrm{d}]$

\section{References}

1. Saif, O. The Future Outlook of Desalination in the Gulf: Challenges \& Opportunities Faced by Qatar \& the UAE. 2012. Available online: http://inweh.unu.edu/wp-content/uploads/2015/05/The-Future-Outlookof-Desalination-in-the-Gulf1.pdf (accessed on 2 January 2017).

2. Al Shehhi, M.R.; Gherboudj, I.; Ghedira, H. An overview of historical harmful algae blooms outbreaks in the Arabian Seas. Mar. Pollut. Bull. 2014, 86, 314-324. [CrossRef] [PubMed]

3. Do Rosário Gomes, H.; Goes, J.L.; Matondkar, S.G.P.; Buskey, E.J.; Basu, S.; Parab, S.; Thoppil, P. Massive outbreaks of Noctiluca scintillans blooms in the Arabian Sea due to spread of hypoxia. Nat. Commun. 2014, 5. [CrossRef] [PubMed] 
4. Missimer, T.M.; Sinha, S.; Ghaffour, N. Strategic Aquifer Storage and Recovery of Desalinated Water to Achieve Water Security in the GCC/MENA Region. Int. J. Environ. Sustain. 2012, 1, 87-99. Available online: https://www.sciencetarget.com/Journal/index.php/IJES/article/viewFile/93/26 (accessed on 2 January 2017). [CrossRef]

5. Hutchinson, C.B. Simulation of Aquifer Storage Recovery of Excess Desalinated Seawater; U.S. Geological Survey Open-File Report 98-410; USGS: Al Ain area, Abu Dhabi Emirate, 1998. Available online: https://pubs.usgs. gov/of/1998/0410/report.pdf (accessed on 2 January 2017).

6. Pyne, R.D.G.; Howard, J.B. Desalination/aquifer storage recovery (DASR): A cost effective combination for Corpus Christi, Texas. Desalination 2004, 165, 363-367. [CrossRef]

7. Dawoud, M.A.; Sallam, O.M. Sustainable Groundwater Resources Management in Arid Regions: Abu Dhabi Case Study; Environmental Agency Abu Dhabi Report; Environmental Agency Abu Dhabi: Abu Dhabi, United Arab Emirates, 2010.

8. German Technical Cooperation Agency. Combined Artificial Recharge and Utilisation of the Groundwater Resource in the Greater Liwa Area (Western Region of the Emirate of Abu Dhabi); Pilot Project Final Technical Report; Deutsche Gesellschaft für Technische Zusammenarbeit (GTZ) GmbH in Co-operation with Dornier Consulting (DCo) GmbH: Bonn, Germany, 2005.

9. German Technical Cooperation Agency. Detailed Design Groundwater Modelling Final Report; Consultancy Services for Artificial Recharge and Utilisation of the Groundwater Resource in the Liwa Area, Consultancy Contract No. G 4877; Deutsche Gesellschaft für Technische Zusammenarbeit (GTZ) GmbH in Co-operation with Dornier Consulting (DCo) GmbH: Bonn, Germany, 2009.

10. German Technical Cooperation Agency. Detailed Design Drilling, Construction and Testing of Recovery and Monitoring Wells Draft Report; Consultancy Services for Artificial Recharge and Utilisation of the Groundwater Resource in the Liwa Area, Consultancy Contract No. G 4877; Deutsche Gesellschaft für Technische Zusammenarbeit (GTZ) GmbH in Co-operation with Dornier Consulting (DCo) GmbH: Bonn, Germany, 2009 ; p. 56.

11. Earth Link \& Advanced Resources Development. Hydrogeological Study and Numerical Groundwater Simulation; Construction Phase Strategic Water Storage and Recovery Project in Liwa Abu Dhabi-United Arab Emirates; Quarterly Report \#6 Hydrogeological Structure and Groundwater Flow \& Transport Model of the SWSR Region; Earth Link and Advanced Resources Development Sarl: Amaret Chalhoub, Lebanon, 2013.

12. Al Futtaim Exova LLC. Test Report of Core Samples; 4 Reports on Respectively Well No: MW 01C, MW11C, MW21 and MW42; Al Futtaim Exova LLC, Lab: Dubai, United Arab Emirates, 2011-2012.

13. Water Quality Regulations 2013-Final Draft Consultation; Regulation and Supervision Bureau Abu Dhabi: Abu Dhabi, United Arab Emirates, 2013.

14. Stuyfzand, P.J. Quality changes upon injection into anoxic aquifers in the Netherlands: Evaluation of 11 experiments. In Artificial Recharge of Groundwater, Proceedings of the 3rd International Symposium on Artificial Recharge, Amsterdam, The Netherlands, 21-25 September 1998; Peters, J.H., Ed.; Balkema: Amsterdam, The Netherlands, 1998; pp. 283-291.

15. Stuyfzand, P.J.; Timmer, H. Deep Well Injection at the Langerak and Nieuwegein sites in the Netherlands: Chemical Reactions and Their Modeling; Kiwa-SWE 99.006; KWR Watercycle Research Institute: Nieuwegein, The Netherlands, 1999; 44p.

16. Stuyfzand, P.J. Pyrite oxidation and side-reactions upon deep well injection. WRI-10. In Proceedings of the 10th International Symposium on Water Rock Interaction, Villasimius, Italy, 10-15 June 2001; Volume 2, pp. 1151-1154.

17. Prommer, H.; Stuyfzand, P.J. Identification of temperature-dependent water quality changes during a deep well injection experiment in a pyritic aquifer. Environ. Sci. Technol. 2005, 39, 2200-2209. [CrossRef] [PubMed]

18. Antoniou, E.A.; van Breukelen, B.M.; Putters, B.; Stuyfzand, P.J. Hydrogeochemical patterns, processes and mass transfers during aquifer storage \& recovery (ASR) in an anoxic sandy aquifer. Appl. Geochem. 2012, 27, 2435-2452.

19. Zuurbier, K.G.; Hartog, N.; Stuyfzand, P.J. Reactive transport impacts on recovered freshwater quality during multiple partially penetrating wells (MPPW-)ASR in a brackish heterogeneous aquifer. Appl. Geochem. 2016, 71, 35-47. [CrossRef]

20. Pyne, R.D.G. Aquifer Storage Recovery—A Guide to Groundwater Recharge through Wells; ASR Systems LLC: Gainesville, FL, USA, 2005. 
21. Price, R.E.; Pichler, T. Abundance and mineralogical association of arsenic in the Suwannee Limestone (Florida): Implications for arsenic release during water-rock interaction. Chem. Geol. 2006, 228, 44-56. [CrossRef]

22. Wallis, I.; Prommer, H.; Simmons, C.T.; Post, V.; Stuyfzand, P.J. Evaluation of Conceptual and Numerical Models for Arsenic Mobilization and Attenuation during Managed Aquifer Recharge. Environ. Sci. Technol. 2010, 44, 5035-5041. [CrossRef] [PubMed]

23. Stuyfzand, P.J.; Smidt, E.; Zuurbier, K.G. Baseline Hydrogeochemistry of the Strategic Water Storage and Recovery Project in Liwa, Abu Dhabi; KWR-Report KWR2014.073; KWR Watercycle Research Institute: Nieuwegein, The Netherlands, 2014.

24. Stuyfzand, P.J.; Hartog, N.; Smidt, E. Prediction of Recovered Water Quality of the Strategic ASR Project in Liwa, Abu Dhabi; KWR-Report KWR2015.003; KWR Watercycle Research Institute: Nieuwegein, The Netherlands, 2014.

25. Stuyfzand, P.J. Simple models for reactive transport of pollutants and main constituents during artificial recharge and bank filtration. In Artificial Recharge of Groundwater, Proceedings of the 3rd Internatioanl Symposium on Artificial Recharge, Amsterdam, The Netherlands, 21-25 September 1998; Peters, J.H., Ed.; Balkema: Amsterdam, The Netherlands, 1998; pp. 427-434.

26. Stuyfzand, P.J. Hydrogeochemcal (HGC 2.1), for Storage, Management, Control, Correction and Interpretation of Water Quality Data in Excel (R) Spread Sheet; KWR-Report BTO2012.244(s); Updated in 2016 December; KWR Watercycle Research Institute: Nieuwegein, The Netherlands, 2016; 92p.

27. Parkhurst, D.L.; Appelo, C.A.J. User's Guide to PHREEQC (Version 2): A Computer Program for Speciation, Batch-Reaction, One-Dimensional Transport, and Inverse Geochemical Calculations; Water-Resources Investigations Report 99-4259.; Open-File Reports Section (Distributor); U.S. Geological Survey: Reston, VA, USA; Earth Science Information Center: Denver, CO, USA, 1999.

28. Wood, W.W.; Clark, D.; Imes, J.L.; Councell, T.B. Eolian Transport of Geogenic Hexavalent Chromium to Ground Water. Ground Water 2010, 48, 19-29. [CrossRef] [PubMed]

29. Wood, W.W.; Imes, J.L. Dating of Holocene groundwater recharge in the Rub al Khali of Abu Dhabi: Constraints on global climate-change models. In Water Resources Perspectives: Evaluation, Management and Policy; Developments in Water Science 50; Alsharhan, A.S., Wood, W.W., Eds.; Elsevier: Amsterdam, The Netherlands, 2003; pp. 379-385.

30. Bottomley, N. Recent climate in Abu Dhabi. In Desert Ecology of Abu Dhabi; Osborne, P.E., Ed.; Pisces Publications: Newbury, UK, 1996; pp. 36-49.

31. World Health Organization. Guidelines for Drinking-Water Quality, 4th ed.; World Health Organization: Geneva, Switzerland, 2011; Available online: http://apps.who.int/iris/bitstream/10665/44584/1/ 9789241548151_eng.pdf (accessed on 15 February 2017).

32. Scheuerman, R.F.; Bergersen, B.M. Injection-water salinity, formation pretreatment, and well operations fluid-selection guidelines. J. Pet. Technol. 1990, 42, 836-845. [CrossRef]

33. Al-Rahman, W.; Maraqa, M. Laboratory investigation of transport and treatment of chromium in groundwater at liwa district, Abu Dhabi. In Proceedings of the 1st International Conference on Natural Resources Engineering \& Technology, Putrajaya, Malaysia, 24-25 July 2006; pp. 338-345.

34. Yolcubal, İ.; Akyol, N.H. Retention and Transport of Hexavalent Chromium in Calcareous Karst Soils. Turk. J. Earth Sci. 2007, 16, 363-379.

35. Richard, F.C.; Bourg, A.C.M. Aqueous geochemistry of chromium: A review. Water Res. 1991, 25, 807-816. [CrossRef]

36. Siever, R. Silica solubility, 0-200 ${ }^{\circ} \mathrm{C}$., and the diagenesis of siliceous sediments. J. Geol. 1992, 70, 127-150. [CrossRef]

37. Ahmad, A.; Kools, S.; Schriks, M.; Stuyfzand, P.J.; Hofs, B. Arsenic and Chromium Concentrations and Their Speciation in Groundwater Resources and Drinking Water Supply in The Netherlands; KWR Report BTO 2015.017; KWR Watercycle Research Institute: Nieuwegein, The Netherlands, 2015.

(C) 2017 by the authors. Licensee MDPI, Basel, Switzerland. This article is an open access article distributed under the terms and conditions of the Creative Commons Attribution (CC BY) license (http:/ / creativecommons.org/licenses/by/4.0/). 